OPEN ACCESS

Edited by:

Thomas Wernberg,

The University of Western Australia,

Australia

Reviewed by:

Guillermo Diaz-Pulido,

Griffith University, Australia

Mads Solgaard Thomsen,

University of Canterbury, New Zealand

Shaun Wilson,

Conservation and Attractions (DBCA),

Australia

*Correspondence.

Alexander J. Fordyce

Alexander.Fordyce@uon.edu.au

Specialty section:

This article was submitted to Global Change and the Future Ocean,

a section of the journal

Frontiers in Marine Science

Received: 18 April 2019

Accepted: 24 July 2019

Published: 16 August 2019

Citation:

Fordyce AJ, Ainsworth TD,

Heron SF and Leggat W (2019)

Marine Heatwave Hotspots in Coral Reef Environments: Physical Drivers, Ecophysiological Outcomes,

and Impact Upon Structural

Complexity. Front. Mar. Sci. 6:498.

doi: 10.3389/fmars.2019.00498

\section{Marine Heatwave Hotspots in Coral Reef Environments: Physical Drivers, Ecophysiological Outcomes, and Impact Upon Structural Complexity}

\author{
Alexander J. Fordyce ${ }^{1 *}$, Tracy D. Ainsworth ${ }^{2}$, Scott F. Heron ${ }^{3,4}$ and William Leggat ${ }^{1}$ \\ ${ }^{1}$ School of Environmental and Life Sciences, The University of Newcastle, Ourimbah, NSW, Australia, ${ }^{2}$ School of Biological, \\ Earth and Environmental Studies, University of New South Wales, Sydney, NSW, Australia, ${ }^{3}$ Laboratory of Marine \\ Geophysical, Department of Physics, College of Science and Engineering, James Cook University, Townsville, QLD, \\ Australia, ${ }^{4}$ NOAA Coral Reef Watch, NESDIS Centre for Satellite Applications and Research, University Research, \\ College Park, MD, United States
}

A changing climate is driving increasingly common and prolonged marine heatwaves (MHWs) and these extreme events have now been widely documented to severely impact marine ecosystems globally. However, MHWs have rarely been considered when examining temperature-induced degradation of coral reef ecosystems. Here we consider extreme, localized thermal anomalies, nested within broader increases in sea surface temperature, which fulfill the definitive criteria for MHWs. These acute and intense events, referred to here as MHW hotspots, are not always well represented in the current framework used to describe coral bleaching, but do have distinct ecological outcomes, including widespread bleaching, and rapid mass mortality of putatively thermally tolerant coral species. The physical drivers of these localized hotspots are discussed here, and in doing so we present a comprehensive theoretical framework that links the biological responses of the coral photo-endosymbiotic organism to extreme thermal stress and ecological changes on reefs as a consequence of MHW hotspots. We describe how the rapid onset of high temperatures drives immediate heat-stress induced cellular damage, overwhelming mechanisms that would otherwise mitigate the impact of gradually accumulated thermal stress. The warm environment, and increased light penetration of the coral skeleton due to the loss of coral tissues, coupled with coral tissue decay support rapid microbial growth in the skeletal microenvironment, resulting in the widely unrecognized consequence of rapid decay, and degeneration of the coral skeletons. This accelerated degeneration of coral skeletons on a reef scale hinder the recovery of coral populations and increase the likelihood of phase shifts toward algal dominance. We suggest that MHW hotspots, through driving rapid heatinduced mortality, compromise reefs' structural frameworks to the detriment of long term recovery. We propose that MHW hotspots be considered as a distinct class of thermal stress events in coral reefs, and that the current framework used to describe coral bleaching and mass mortality be expanded to include these. We urge further research into how coral mortality affects bioerosion by coral endoliths. 


\section{CORAL BLEACHING AND THE EMERGENCE OF MARINE HEATWAVES}

It has now been well established that warming oceans compromise the symbiotic relationship that hard corals share with single-celled dinoflagellates known as zooxanthellae (Symbiodiniaceae, Suessiales) (Muscatine and Porter, 1977; LaJeunesse et al., 2018). Normally, the zooxanthellae that reside within corals' gastrodermal tissue fix carbon through photosynthesis and thereby support the growth and survival of tropical corals (Muscatine and Porter, 1977). The sugars and other organics produced through photosynthesis are translocated to the coral host, meeting its metabolic requirements in the nutrient-poor waters that most corals inhabit (Muscatine and Porter, 1977; Yellowlees et al., 2008). However, when the temperature of the surrounding seawater increases beyond what can be tolerated by the coral host and/or algal symbiont, cellular dysfunction disrupts this symbiosis (Hoegh-Guldberg, 1999). As the partnership breaks down, the coral colony goes white, due to a loss of symbionts and/or a degradation of their pigments which leaves the coral skeleton visible through the now transparent, and symbiont-depleted host tissues (Hoegh-Guldberg, 1999). This phenomenon is therefore known as coral bleaching (Table 1) and generally reduces the survivorship of corals during times of environmental stress (Grottoli et al., 2006; Anthony et al., 2009).

In the last 20 years, the prevalence and intensity of mass coral bleaching events triggered by anomalously warm SSTs has increased (Heron et al., 2016; Frolicher and Laufkotter, 2018; Hughes et al., 2018a). For example, on the GBR mass coral bleaching was observed in 1998, 2002, and 2015-2017 (Berkelmans et al., 2004; Heron et al., 2016; Hughes et al., 2017). Comparisons of the 1998, 2002, and 2015-2017 bleaching events highlighted the unprecedented scale and severity of the most recent event which affected nearly two-thirds of the 2,300 km long system (Hughes et al., 2017). This was driven by an increase in the relative proportion of individual reefs experiencing severe thermal stress (Hughes et al., 2017). These observations are reflective of the global trend in the intensity of coral bleaching events throughout the Anthropocene (Hughes et al., 2018a). The intensity and frequency of marine heatwaves (MHWs) in the same time period has also increased (Oliver et al., 2018). MHWs have recently been defined as a period in which the water temperature is above the 90th percentile for that area's historical conditions for five or more days, where the climatological threshold is a time-of-year dependent 11-day shifting window (Hobday et al., 2016). MHWs represent the most extreme and "rare" incidences of thermal stress relative to a season-dependent historical baseline (Hobday et al., 2016). However, this definition has only recently been applied, for the first time, to the study of coral bleaching events (Smale et al., 2019) though this considered the annual accumulation of MHW days rather than individual events.

For over two decades, the degree heating week (DHW) product of the NOAA Coral Reef Watch (Liu et al., 2017) has been the standard metric for measuring, comparing and predicting accumulated heat stress, referenced to the historically warmest time of the year ("summertime") in coral reef environments. DHWs represent the duration of thermal anomalies experienced by corals, accumulated across a three month period (Liu et al., 2005). In this instance, positive temperature anomalies are calculated above the maximum of the monthly mean (MMM) threshold, which is the temperature of the climatologically warmest month for an area (Heron et al., 2014; Liu et al., 2017). When DHW values reach $4^{\circ} \mathrm{C}$ weeks, coral reefs are predicted to experience mild bleaching, while greater than $8^{\circ} \mathrm{C}$-weeks has been associated with severe bleaching and widespread mortality (Liu et al., 2005). DHWs allow for the broad tracking of the accumulation of heat in a water body over a relatively long time frame and can be used to infer some physiological heat stress responses (Liu et al., 2005).

The degree heating week approach, while powerful, has not always detected intense, acute events that are able to cause significant coral bleaching, particularly those that are spatially restricted (Weeks et al., 2008; Bainbridge, 2017; DeCarlo et al., 2017). For example, intense heating in the southern GBR in 2006 caused bleaching in more than $90 \%$ of surveyed corals in the Keppel Islands (Weeks et al., 2008) but was insufficient to trigger alerts when relying solely upon the DHW approach due to ocean heating occurring earlier than usual outside of the summer season. Likewise, extreme heating in 2015 on the Dongsha Atoll drove temperatures to $6^{\circ} \mathrm{C}$ above the climatological mean and the mass mortality of $40 \%$ of the local coral population was observed (DeCarlo et al., 2017). The short-lived and localized nature of the heating meant large-scale satellite monitoring did not capture the event and alert systems failed due to a reliance on accumulation of heat over extended periods, which did not occur. In this case the rapid onset of warming within less than a week and persistence of these high temperatures for more than 5 days (DeCarlo et al., 2017) would qualify the event as a MHW (Hobday et al., 2016). Similarly, the peak of thermal stress on Thursday Island during the 2016 mass bleaching event was not accurately represented when using traditional remote sensing techniques (Bainbridge, 2017). Temperatures increased from the climatological baseline to well above the 99th percentile within less than a month, and this persisted for 11 days (Bainbridge, 2017), qualifying the event as a strong MHW (Hobday et al., 2018). While the accumulated thermal stress in this area eventually peaked at $14^{\circ} \mathrm{C}$-weeks in mid-May, this was almost 2 months after the occurrence of the majority of mass mortality (Great Barrier Reef Marine Park Authority, 2016; Hoogenboom et al., 2017; Hughes et al., 2017).

Marine heatwaves do not always translate into a meaningful value for DHWs, and this is particularly relevant when predicting the ecological and physiological outcomes of these events. During the 2011 massive thermal anomaly off the coast of Western Australia, $\geq 16^{\circ} \mathrm{C}$-weeks was recorded across approximately $1200 \mathrm{~km}$ along the coast (Moore et al., 2012). The most intense heating, around the Houtman Abrolhos Islands, was also represented by a 95-day MHW (Hobday et al., 2016) and triggered mass coral bleaching (Smale and Wernberg, 2012). Here, a new "extreme" category of DHWs might complement the existing "mild" and "severe" thresholds and serve to represent MHWs. However, acute and intense summertime MHWs can occur independently of high corresponding DHW values. For 
TABLE 1 | Common and key terms, and their definitions, used in this review.

\begin{tabular}{|c|c|c|}
\hline Term & Definition & Source \\
\hline Acclimatization & $\begin{array}{l}\text { The behavioral or physiological changes of an organism to increase the endurance of or reduce the } \\
\text { source of cellular stress arising from changes in the environment }\end{array}$ & Bowler, 2005 \\
\hline Antioxidants & $\begin{array}{l}\text { A class of enzymes or compounds that scavenge reactive oxygen species (see below) and so } \\
\text { prevent cellular oxidative stress. The following are commonly studied in the context of coral } \\
\text { bleaching: superoxide dismutase (SOD), glutathione reductase (GR), ascorbate peroxidase (APX), } \\
\text { catalase (CAT), and dimethyl sulfoxide (DMSO) }\end{array}$ & $\begin{array}{l}\text { Krueger et al., 2014, 2015; } \\
\text { Roberty et al., 2015; Gardner } \\
\text { et al., } 2017\end{array}$ \\
\hline Coral bleaching & $\begin{array}{l}\text { The disassociation between corals and their colored endosymbiotic algae due to cellular stress, } \\
\text { resulting in a characteristic white appearance. Commonly a result of thermal stress. When this is } \\
\text { driven by light stress only, it is referred to as photo-bleaching }\end{array}$ & Lesser, 1997 \\
\hline Degree heating weeks & $\begin{array}{l}\text { A measure of heat stress combining the effects of magnitude and duration of SST that exceeds the } \\
\text { expected summertime conditions (MMM), accumulated across a rolling 12-week period }\end{array}$ & Liu et al., 2005 \\
\hline Endolithic microborers & Microbial, boring organisms living within rocks, shells, and coral skeletons & Tribollet, 2008b \\
\hline $\begin{array}{l}\text { Marine heatwaves } \\
(\mathrm{MHWs})\end{array}$ & $\begin{array}{l}\text { A period of } \geq 5 \text { days wherein the temperature is above the 90th percentile of historically observed } \\
\text { values for that location for that time of year }\end{array}$ & Hobday et al., 2016 \\
\hline MHW hotspots & $\begin{array}{l}\text { Localized thermal extremes nested within regional SST anomalies that are not accurately } \\
\text { represented using the DHW framework, but fulfil the above criteria for an MHW }\end{array}$ & This review \\
\hline Mass mortality & An ill-defined term. Previously used to described mortality prevalence of greater than $30 \%$ & Hughes et al., 2017 \\
\hline $\begin{array}{l}\text { Maximum of the } \\
\text { monthly mean (MMM) }\end{array}$ & $\begin{array}{l}\text { The location-specific SST representative of expected summertime conditions, determined as the } \\
\text { warmest monthly climatological SST with a baseline period in the late } 1980 \text { s }\end{array}$ & Liu et al., 2014 \\
\hline Microbioerosion (corals) & Chemical dissolution of aragonite skeleton by endolithic microborers & Tribollet, 2008b \\
\hline Phase shift & $\begin{array}{l}\text { Shifts between alternative stable states of an ecosystem. In coral reefs, this is typically between } \\
\text { coral- and algal-dominated benthos }\end{array}$ & Idjadi et al., 2006 \\
\hline $\begin{array}{l}\text { Reactive oxygen } \\
\text { species (ROS) }\end{array}$ & $\begin{array}{l}\text { Oxygen radicals produced as by-products of photosynthesis and respiration, with the potential to } \\
\text { damage lipids, proteins and DNA: superoxide }\left(\mathrm{O}_{2}^{-}\right) \text {, hydrogen peroxide }\left(\mathrm{H}_{2} \mathrm{O}_{2}\right) \text {, singlet oxygen } \\
\left({ }^{1} \mathrm{O}_{2}\right) \text {, and hydroxyl }\left(\mathrm{OH}^{-}\right)\end{array}$ & Murphy, 2009 \\
\hline $\begin{array}{l}\text { Sea surface } \\
\text { temperature (SST) } \\
\text { anomalies }\end{array}$ & $\begin{array}{l}\text { The variation in SST from what is expected to occur at each location at the specific time of year. } \\
\text { Expected values are typically defined using a long-term climatology }\end{array}$ & Liu et al., 2005 \\
\hline
\end{tabular}

example, at the peak of the MHW on Thursday Island in 2016 the corresponding DHW value was approximately six (Bainbridge, 2017). In the same study, water temperatures around Lizard Island were recorded as increasing to around the 95th climatological percentile, where they remained for 9 days (Bainbridge, 2017). A corresponding DHW value of $4^{\circ} \mathrm{C}$-weeks would predict mild coral bleaching, in stark contrast to the observed extent and severity of coral bleaching and mortality around Lizard Island (Hoogenboom et al., 2017; Hughes et al., 2017). Using the online Marine Heatwave Tracker $^{1}$ (Schlegel, 2018), this same event is categorized as a "II Strong" MHW using the classification system proposed by Hobday et al. (2018).

In addition to the improved detection of short-lived, intense thermal anomalies, the application of the MHW criteria also allows us to consider thermal stress outside of summer months. As the accumulation of DHWs is based on the exceedance of summertime maxima, this limits application to this season. Yet there is evidence that thermal stress outside of this period can have significant impacts on marine environments and are captured using season-dependent shifting climatological baselines (Weeks et al., 2008; Hobday et al., 2016, 2018). But while it is known that cold temperatures can lead to cold water coral bleaching (Hoegh-Guldberg and Fine, 2004; Lirman et al., 2011), as yet we have little information on the effects of positive winter anomalies on corals. Berkelmans and Willis (1999) examined

\footnotetext{
${ }^{1}$ http://www.marineheatwaves.org/tracker
}

seasonal changes in bleaching thresholds for the coral Pocillopora damicornis and found the thresholds decreased by only $1^{\circ} \mathrm{C}$ from summer to winter, suggesting that seasonal acclimatization may not reduce thresholds to such an extent that winter bleaching will occur during a winter MHW. There is, however, evidence that water temperatures in the winter can affect coral disease progression and susceptibility. Sato et al. (2009) identified a correlation between lower winter temperatures and the lower infectivity and progression in black band disease while a large scale temporal analysis by Heron et al. (2010) found that mild winters (i.e., neither anomalously hot or cold) frequently preceded outbreaks of coral white syndrome in the following year. The observation that disease outbreaks did not generally follow warmer winters suggest that winter $\mathrm{MHW}$ s have the capacity to significantly influence coral physiology in the long term. This is an important area for future exploration given that coral tissue biomass is higher in the winter and early spring (Fitt et al., 2000) and influences coral bleaching responses (Fitt et al., 2009). These periods are likely important for resource provisioning leading into coral spawning and summertime.

Examining thermal stress in coral reef environments using a MHW approach can therefore add a new dimension to how we understand, detect and measure coral bleaching and mortality events to the benefit of our present alert systems. The cases outlined here demonstrate firstly that extreme and small scale coral bleaching and mortality events, which do not accumulate DHWs above thresholds needed to trigger alerts, can be identified 
using MHW criteria. When used in conjunction with DHWs, this may improve our ability to predict fine scale ecological patterns during mass coral bleaching events. Secondly, that mismatches between low DHW values and severe ecological degradation can be reconciled by applying MHW criteria in explaining causative factors of mass coral mortality. This evidence provides a means to improve the accuracy of our predictions of the responses of reef communities when these values are considered alongside an understanding of the biological responses to the thermal conditions. It is important to consider MHWs as acute, intense events disparate from those characterized by chronic heat accumulation, and independent of the existing DHW scale. As summertime MHWs are often nested within broader thermal anomalies, the term "MHW hotspots" as used in this review represents the most extreme patches of thermal stress, and the distinct ecological and physiological responses that occur within these.

\section{THE EVOLUTION OF MHW HOTSPOTS}

Marine heatwaves hotspots are often the result of combined regional heating and local weather patterns, which interact to promote the rapid accumulation of heat (Skirving et al., 2006; MacKellar and McGowan, 2010; Wernberg et al., 2012; Bainbridge, 2017; DeCarlo et al., 2017). Abiotic factors that influence these events include tidal cycles, calm winds, clear skies and low water flow, which act to amplify regional thermal stress

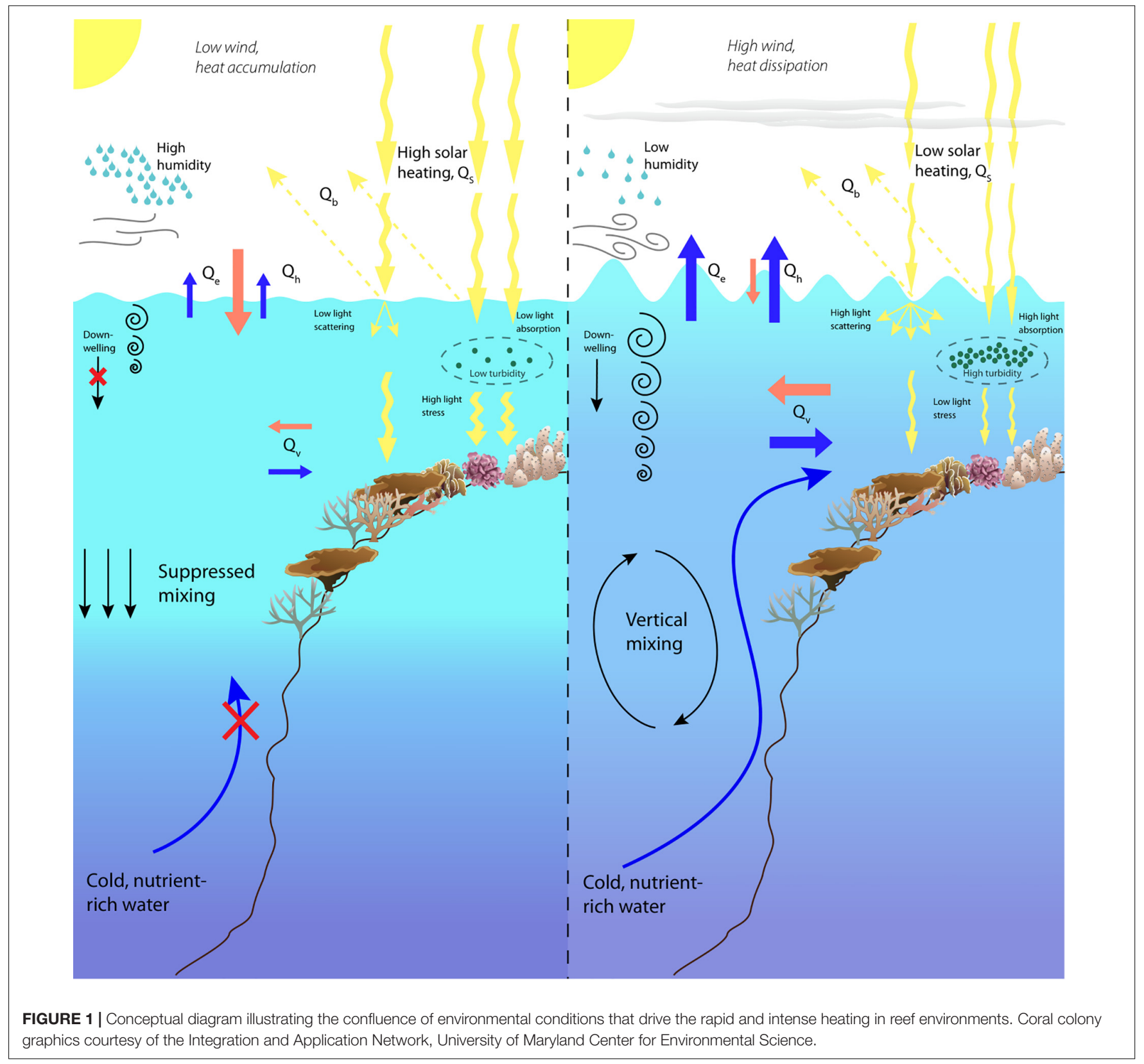


on the scale of individual reefs (Figure 1; Skirving et al., 2006; MacKellar and McGowan, 2010; Baird et al., 2017; Raymundo et al., 2017; Burt et al., 2019). Potentially the most commonly cited driver of thermal extremes in coral reef environments is a drop in wind speed (Baird et al., 2009; Bainbridge, 2017; Burt et al., 2019). Wind influences most components of the oceanic heat budget (Figure 1; Talley et al., 2011; Lowe and Falter, 2014), in part through how it affects currents and wave action (Davis et al., 2011; MacKellar et al., 2013). However, these latter factors are not always forced by local wind patterns and can have distinct effects upon heat accumulation and physiological responses (Nakamura, 2010; Lentz et al., 2016). There is therefore often a mismatch between the scale of a MHW hotspot and the resolution of available satellite imagery, due to the influence of these abiotic factors at the reef-scale. The confluence of these physical drivers is physiologically significant for reef corals and determines the severity of the bleaching process. High insolation maximizes the heat and light stress experienced by corals, which act synergistically to drive and exacerbate coral bleaching and mass mortality in time frames directly related to the intensity of environmental stress (Jones et al., 1998; Lesser and Farrell, 2004; Skirving et al., 2017).

The highest potential for heat loss from a water body results from evaporative cooling i.e., latent heat flux $\left(Q_{e}\right)$ (Figure 1; Talley et al., 2011). Weller et al. (2008) attributed coral bleaching on the GBR in 2001/2002 primarily to low wind and resultant low evaporation. Indeed, evaporative cooling has been shown to be strongly coupled to wind speed because of how this affects the air-sea temperature difference (Wu et al., 2007; MacKellar and McGowan, 2010; MacKellar et al., 2013; DeCarlo et al., 2017). When wind speeds drop to negligible levels, evaporation quickly leads to high humidity at the air-sea interface which reduces the potential for further evaporative cooling (Wu et al., 2007; Weller et al., 2008; MacKellar and McGowan, 2010). Additionally, this increases the air's heat capacity and promotes air-to-sea heat transfer through sensible heat flux $\left(Q_{h}\right)$ (Figure 1; Weller et al., 2008; DeCarlo et al., 2017). Reductions in wind speed often precede increases in SSTs and a number of case studies have identified a reduction in wind speed with subsequent increases in humidity and heat accumulation. Two small scale bleaching events, at Lee Stocking Island in 1990 (Smith, 2001) and on the sub-tropical Heron Reef in 2009 (MacKellar and McGowan, 2010), linked a drop in wind speed below $3 \mathrm{~ms}^{-1}$ to an increase in humidity and reduction in evaporative cooling. In the case of the latter, the daytime maximum temperature increased to $>34^{\circ} \mathrm{C}$ in a matter of days and caused short term coral bleaching (MacKellar and McGowan, 2010). Similarly, the most extreme temperatures recorded at a depth of $6.5 \mathrm{~m}$ by Burt et al. (2019), in the southern Arabian Gulf, were strongly correlated with wind speeds below a local threshold of $4 \mathrm{~ms}^{-1}$. These values, as well as that identified by Bainbridge (2017) $\left(2.8 \mathrm{~ms}^{-1}\right)$, lend credence to the threshold chosen by NOAA $\left(3 \mathrm{~ms}^{-1}\right)$ in defining doldrumlike winds in relation to coral bleaching (Liu et al., 2012).

On a larger scale, a reduction in wind speed was linked to widespread warming during the 2001/2002 mass bleaching event on the GBR (Weller et al., 2008) and the 2015 thermal anomaly in the South China Sea that underpinned the mass mortality event on the Dongsha Atoll (DeCarlo et al., 2017). These studies also identified increased air-to-sea sensible heat flux resulting from increases in humidity. In the converse scenario, strong winds promote cooling and are able to reduce temperatures by several degrees, especially at night (MacKellar et al., 2013). This is thought to be an important cellular recovery period after damage sustained by daytime maxima (Roberty et al., 2015). Thus, negligible wind speeds and associated rapid heat accumulation not only increases daytime heat stress but also possibly reduces the potential for night-time recovery.

Accompanying doldrum-like wind speeds is a reduction in sea surface turbulence which would otherwise promote cooling. A flat ocean surface acts as a viscous boundary layer at the airsea interface and significantly limits sea-to-air heat flux (Moum and Smyth, 2001; Grant and Belcher, 2011). This promotes the accumulation of heat in surface waters and thermal stratification in the water column (Van Hooidonk et al., 2013; Lowe and Falter, 2014; Zhang et al., 2016). Exacerbating this effect, flat seas generate little to no downwelling (Moum and Smyth, 2001). In contrast, strong winds generate shear-induced turbulence at the air-sea interface which leads to small pockets of cool water that sink down through the upper layer (Moum and Smyth, 2001; Grant and Belcher, 2011). This downwelling destabilizes a stratified water column and aids in distributing heat from insolation away from surface waters (Figure 1; Moum and Smyth, 2001; Lowe and Falter, 2014). A lack of wind-generated wave action therefore promotes a positive feedback loop in which heat accumulation stabilizes thermal strata which in turn allows for a greater heat load in surface waters (Figure 1). Oceanic swell can generate wave-related surface cooling independent of wind conditions; however, the rapid dissipation of wave energy by fore reef environments limits the spatial extent of this mechanism (Lowe and Falter, 2014). Wind-driven turbulence, on the other hand, can extend into reef lagoons, and cause significant cooling by vertical mixing (MacKellar et al., 2013).

A lack of wind forcing and wave action often results in low levels of water circulation and heat exchange with the open ocean (Davis et al., 2011; Lentz et al., 2016; DeCarlo et al., 2017). Advection (i.e., horizontal water movement, $Q_{v}$ ), or a lack thereof, has been proposed as a key determinant of the accumulation of heat on coral reefs (Figure 1; MacKellar et al., 2013; Lowe and Falter, 2014). Flushing reefs with cool water from deeper surroundings can lower daytime maximum temperatures and reduce diurnal variation (Davis et al., 2011; MacKellar et al., 2013; DeCarlo et al., 2017). Additionally, currents have been shown to promote vertical mixing independent of wave-driven down-flow (DiMassa et al., 2010). Circulation is controlled by surface wind-driven currents (Lowe and Falter, 2014), waves (Lentz et al., 2016), and tidal cycles (MacKellar et al., 2013). The more sheltered the reef environment, the more dependent it is upon circulation driven by wind and wind-generated waves (Davis et al., 2011; Lentz et al., 2016). In MHW hotspots, the lack of wind and waves therefore limits circulation and advective cooling (DeCarlo et al., 2017; Van Wynsberge et al., 2017). As a result, water has high residency time, pools over the reef and heats up rapidly (DeCarlo et al., 2017; Van Wynsberge et al., 2017). Tidal flushing can, in some cases, offset heat 
accumulation considerably (MacKellar and McGowan, 2010; Lowe and Falter, 2014) while neap tides and weak intertidal currents have been identified as causal factors for intense heating (DeCarlo et al., 2017). Conversely, mass mortality has also been associated with large spring tides during regional low-stand periods that drove increased subaerial exposure (Raymundo et al., 2017). Therefore, the effect of tidal cycles on coral bleaching and mortality is likely to be highly dependent upon a reef's bathymetry and tidal range.

Doldrum-like winds and the associated physical outcomes are often representative of broad areas of high atmospheric pressure (MacKellar and McGowan, 2010; Bainbridge, 2017; Couch et al., 2017). The consequence is increased solar irradiance $\left(Q_{S}\right)$ (Figure 1), which is the primary source of heat input on coral reefs, and has been linked to the rapid onset of thermal stress (Davis et al., 2011; MacKellar et al., 2013; DeCarlo et al., 2017). High irradiance is also a primary source of stress as it drives oxidative stress in symbiotic algae through the production of reactive oxygen species (ROS) (Jones et al., 1998; HoeghGuldberg, 1999; Krug et al., 2013). The effect of high cloud cover in reducing coral bleaching intensity is well documented (Berkelmans et al., 2004; Zelinka and Hartmann, 2010; Hughes et al., 2017), particularly when tropical cyclones pass over coral reefs, and simultaneously cool surface waters through wind exposure (Manzello et al., 2007; Carrigan and Puotinen, 2011). Water column stratification can increase light stress by reducing light attenuation of suspended particulates (through absorption and/or backscatter) in the surface layers (Manzello et al., 2004; Zepp et al., 2008). The opposite effect (i.e., suspended particulates reducing light stress) is apparent when we observe high coral bleaching tolerance on turbid inshore reefs compared to offshore reefs with high water clarity (Morgan et al., 2017). Additionally, flat seas minimize light scattering through surface turbulence and so maximize the intensity of light experience by corals and their symbionts. Combined with the high accumulation of heat, increased light is able to rapidly overcome corals' mechanisms of physiological resilience in short time frames.

\section{ECOLOGICAL CONSEQUENCES OF MHW HOTSPOTS}

The impact of MHW hotspots on coral populations can be ecologically distinct from what is understood of traditional bleaching events. The first compelling evidence for $\mathrm{MHW}$ hotspots leading to distinct ecological outcomes, is that they cause widespread bleaching and mortality in corals that would normally be categorized as thermally tolerant "winners" during milder events (Loya et al., 2001; Hoogenboom et al., 2017; Hughes et al., 2018b). In their study of the Dongsha Atoll, DeCarlo et al. (2017) used coral cores of a thermally tolerant Porites sp. to examine historical bleaching in the reef lagoon. In the previous 100 years, no more than $50 \%$ of the population had bleached during any one event (DeCarlo et al., 2017). In contrast, $100 \%$ of this species bleached during the acute 2015 event where temperatures peaked at $6^{\circ} \mathrm{C}$ over the climatological mean (DeCarlo et al., 2017). In a similar case, Hoogenboom et al. (2017) examined the responses of Acroporids during the extreme 2016 anomaly on Lizard Island. The authors highlighted how species that exhibited high thermal tolerance during previous mass bleaching events on the GBR in 1998 and 2002 experienced widespread and indiscriminate bleaching in mid-to-late March (Hoogenboom et al., 2017). This coincided with the temperatures spiking above the 95th climatological percentile (Bainbridge, 2017). The ability for extreme, acute thermal stress to overcome the protective mechanisms of otherwise heat tolerant species was also evident in regions where corals have adapted to naturally extreme environments. Corals in the Arabian Gulf have some of the highest bleaching thresholds, partly due to the selective pressure of maximum summer temperatures exceeding $34^{\circ} \mathrm{C}$ annually (Riegl et al., 2011). Between August and September 2017, these thermally tolerant coral populations experienced mass bleaching and mortality following up to 20 consecutive days above their lethal threshold of $35.5^{\circ} \mathrm{C}$, less than two degrees Celsius above the climatological summertime maximum (Shuail et al., 2016; Burt et al., 2019). Even in the context of this naturally warm environment, the non-selective bleaching of thermally tolerant coral populations was considered unusual and extreme (Burt et al., 2019). Similarly, during the 2014-2017 global coral bleaching event (Eakin et al., 2017), mass bleaching of thermally tolerant corals in the southern Kimberley region of northwestern Australia was observed (Le Nohaïc et al., 2017). This population is considered to be relatively resistant to climatic extremes (Schoepf et al., 2015) and indeed this was the first recorded instance of coral bleaching at these extreme, inshore reefs (Gilmour et al., 2019). However, while heat stress of $11.4^{\circ} \mathrm{C}$-weeks drove this extreme response, further north reefs exposed to $14.8^{\circ} \mathrm{C}$-weeks showed little to no bleaching (Gilmour et al., 2019). This supports the notion that DHWs are not accurately predicting ecological responses during these extreme events.

Finally, the rate of heating during a MHW hotspot can drive uncharacteristically rapid onset of bleaching and mortality. For example, water temperatures in the Keppel Islands, 2006, reached summertime maxima in December as opposed to February which would normally be the result of long-term accumulation of heat (Weeks et al., 2008). By mid-January, between 77 and 95\% of coral colonies exhibited bleaching (Diaz-Pulido et al., 2009) due to both the rate and seasonal timing of heat accumulation (Weeks et al., 2008). During the 2016 event on Lizard Island, healthy coral-dominated reefs transitioned through mass bleaching and mortality to algal-domination in approximately 6 weeks (Hoogenboom et al., 2017; Hughes et al., 2017). This timeline is remarkably similar to that recorded on the Dongsha Atoll, where mass mortality occurred in less than 6 weeks (DeCarlo et al., 2017). The accelerated rate of mortality associated with the rapid accumulation of heat is further exemplified by observations of coral mortality in Iriomote 2 weeks after the initial onset of thermal stress driven primarily by doldrum-like wind speeds (Baird et al., 2017). These timescales are in contrast to normal bleaching events, where coral bleaching typically occurs following several months of heat stress (Weeks et al., 2008; Liu et al., 2014). In the most extreme examples, this accelerated heating can even 
lead to coral mortality without prior bleaching as observed on the GBR in 2016 (Hughes et al., 2017). This is likely a combined result of increased heat damage to coral host cells and higher in situ degradation of symbionts observed during extreme thermal stress (Strychar et al., 2004; Strychar and Sammarco, 2009).

These ecological observations of MHW hotspots overcoming thermal tolerance and causing mass bleaching and/or mortality in short time frames indicates that mechanisms usually associated with coral acclimatization or resistance to high temperatures are being overcome during these extreme events. Typical coral bleaching events often result in the emergence of thermally tolerant "winners" and thermally susceptible "losers" within a coral reef community (Loya et al., 2001), selecting for those most thermally tolerant coral species (see Table 2). When subjected to extreme MHW hotspots however, the interspecific differences in coral thermal tolerance that underpin this paradigm appear

TABLE 2 | Examples of coral genera and species reported to have high or low thermal tolerance.

\begin{tabular}{|c|c|c|c|c|c|}
\hline \multicolumn{2}{|c|}{ GENUS } & \multicolumn{4}{|c|}{ SPECIES } \\
\hline Genus & Tolerance & Species & Tolerance & Location & Source \\
\hline \multirow[t]{7}{*}{ Acropora spp. } & Low & A. digitifera & Low & Okinawa, Japan & Loya et al., 2001; Van Woesik et al., 2004 \\
\hline & & A. gemmifera & Low & Okinawa, Japan & Van Woesik et al., 2004 \\
\hline & & A. hyacinthus & Low & GBR, Aust. & Baird and Marshall, 2002 \\
\hline & & A. millepora & Low & GBR, Aust. & $\begin{array}{l}\text { Baird and Marshall, 2002; Berkelmans and } \\
\text { Van Oppen, } 2006\end{array}$ \\
\hline & & A. tenuis & High & GBR, Aust. & Camp et al., 2018 \\
\hline & & Acropora sp. & Low & Mombasa, Kenya & McClanahan et al., 2004 \\
\hline & & & High & GBR, Aust. & \\
\hline \multirow[t]{2}{*}{ Agaricia spp. } & Low & A. agaricites & High & Jamaica, Caribbean & Fitt and Warner, 1995 \\
\hline & & A. lamarcki & Low & & \\
\hline Favites spp. & High & F. halicora & High & Okinawa, Japan & Loya et al., 2001 \\
\hline \multirow[t]{2}{*}{ Goniastrea spp. } & Low & G. aspera & High & $\begin{array}{l}\text { Okinawa, Japan; } \\
\text { Phuket, Thailand }\end{array}$ & Loya et al., 2001; Brown et al., 2014 \\
\hline & & G. pectinata & High & Okinawa, Japan & Loya et al., 2001 \\
\hline \multirow[t]{2}{*}{ Leptastrea spp. } & High & L. purpurea & High & Okinawa, Japan & Loya et al., 2001 \\
\hline & & L. transvera & High & Okinawa, Japan & Loya et al., 2001 \\
\hline \multirow[t]{2}{*}{ Montastrea spp. } & High & $\begin{array}{l}\text { M. annularis } \\
\text { (Orbicella annularis) }\end{array}$ & Low & Jamaica, Caribbean & Fitt and Warner, 1995 \\
\hline & & M. cavernosa & High & & \\
\hline \multirow[t]{2}{*}{ Montipora spp. } & Low & M. aequituberculata & Low & Okinawa, Japan & Loya et al., 2001 \\
\hline & & M. digitata & High & GBR, Aust. & Nitschke et al., 2018 \\
\hline \multirow[t]{3}{*}{ Pavona spp. } & Low & P. minuta & High & Okinawa, Japan & Van Woesik et al., 2004 \\
\hline & & P. varians & & & \\
\hline & & P. clavus & Low & Phuket, Thailand & Phongsuwan and Chansang, 2012 \\
\hline \multirow[t]{2}{*}{ Platygyra spp. } & Low & P. daedalea & High & GBR, Australia & Baird and Marshall, 2002 \\
\hline & & Pryukuensis & High & Okinawa, Japan & Loya et al., 2001 \\
\hline \multirow[t]{3}{*}{ Pocillopora spp. } & Low & P. damicornis & Low & Okinawa, Japan & Loya et al., 2001 \\
\hline & & & High & Eilat, Red Sea & Grottoli et al., 2017 \\
\hline & & P. verrucosa & High & Okinawa, Japan & Van Woesik et al., 2004 \\
\hline \multirow[t]{7}{*}{ Porites spp. } & High & $P$. attenuata & Low & Okinawa, Japan & Loya et al., 2001 \\
\hline & & P. cylindrica & Low & & Loya et al., 2001 \\
\hline & & & High & & Van Woesik et al., 2004 \\
\hline & & P. lutea & High & Phuket, Thailand & Brown et al., 2014 \\
\hline & & P. nigriscens & Low & Okinawa, Japan & Loya et al., 2001 \\
\hline & & Porites sp. & Low & Mombasa, Kenya & McClanahan et al., 2004 \\
\hline & & & High & GBR, Aust. & \\
\hline \multirow[t]{2}{*}{ Stylophora spp. } & Low & S. pistillata & Low & Okinawa, Japan & Loya et al., 2001 \\
\hline & & & High & Gulf of Aqaba, Red Sea & Krueger et al., 2017 \\
\hline
\end{tabular}

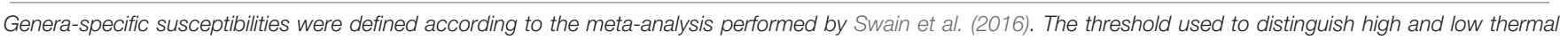

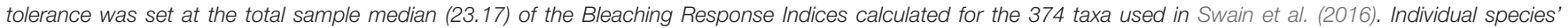

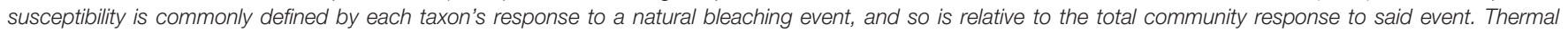
tolerance is influenced by location and environmental history, but shows taxon-specific consistency across locations (McClanahan et al., 2004; Swain et al., 2016). 
to be less important in shaping community responses, given the extensive bleaching and mortality observed in putatively tolerant coral species.

\section{CORAL THERMAL STRESS RESPONSES AND MHWS}

Thermal stress events have a variety of impacts on the coral photo-endosymbiotic organism. These range from sub-lethal effects, which may reduce fitness, to mortality that is most often associated with starvation due to the breakdown of the coral-algal symbiosis (Hoegh-Guldberg, 1999; Anthony et al., 2009; Tables 1, 3). Coral species are generally described in categories of thermal stress susceptibility, ranging from slow growing species with massive growth forms, such as Porites spp., which have high tolerance to thermal stress to fast growing branched species, such as Acropora spp., which are considered to have low tolerance (Table 2). The thermal tolerance of a species in a specific coral reef location is determined by a complex interplay of factors. While there is some consistency over large spatial scales (Table 2), the current and historical environmental conditions at a particular reef drive intraspecific physiological and morphological differences. These include: characteristics of the corals growth form and skeletal phenotype (massive vs. branching morphology) (Loya et al., 2001); capacity for and extent of heterotrophic feeding (Grottoli et al., 2006); dominant symbiont type (e.g., thermally tolerant clade D vs. susceptible symbiont clade C) (Berkelmans and Van Oppen, 2006); acclimatization potential (Gates and Edmunds, 1999); and adaptive tolerance to thermal stress (Coles and Brown, 2003). There is a spectrum of traditional responses by the coral animal to thermal stress, ranging from short-lived photobleaching, where photosynthetic efficiency is reduced often accompanied by a reduction in photosynthetic pigments, and through to mortality of the host animal from starvation (Table 3). This spectrum has been used to model the future characteristics of reefs under climate change scenarios under the assumption that, in general, as thermal stress accumulates within an event corals progress through each stage of this scale at different rates reflective of the animals' resilience and the severity of the stress (Donner et al., 2005). This is generally consistent across different bleaching events, although there are exceptions and there is mounting evidence that animals' resilience can be altered within one generation due to acclimatization (Coles and Brown, 2003). However, under conditions concomitant with a MHW hotspot, this progression of the thermal bleaching response is no longer evident. Instead, the responses typical of acclimatization (see Table 4) are absent, corals exhibit signs of direct heat damage and mortality can happen in a matter of days (Leggat et al., 2019), potentially without prior bleaching (Hughes et al., 2017). This is due to the intensity of these thermal stress events overwhelming corals' ability to cope in the short term, bypassing the meta-organism's bleaching process and instead resulting in heat-induced mortality of the coral animal. This is a distinct physiological outcome of extreme thermal stress compared to how we traditionally consider bleaching-induced mortality (i.e., the progressive breakdown of symbiosis leading to mortality from starvation).

While both the coral host and its symbiont are physiologically challenged by the temperature stress associated with historical coral bleaching events (Baird et al., 2009), the symbiont has been considered as the more thermally sensitive partner in the symbiosis (Jones et al., 1998; Hoegh-Guldberg, 1999; Krug et al., 2013). This widely accepted understanding of coral bleaching has driven substantial research into determining the mechanisms underpinning damage to the endosymbiotic photosystems, a process generally described as photo-bleaching

TABLE 3 | The range of ecological and physiological responses of corals to varying degrees of environmental stress.

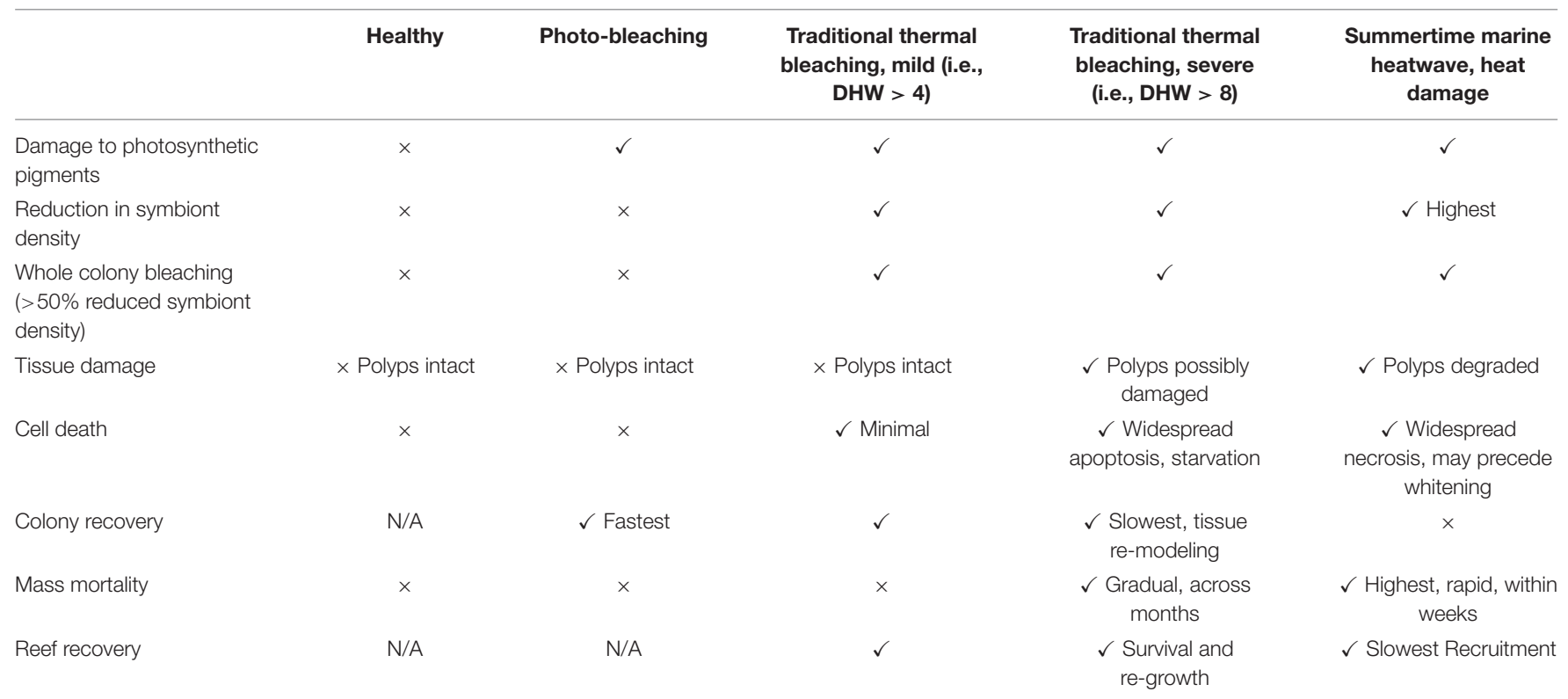


TABLE 4 | Demonstrated acclamatory responses of coral host and/or symbiotic algal cells to thermal stress.

\begin{tabular}{|c|c|c|}
\hline Cellular component & Acclimatory response & Source \\
\hline Heat shock proteins (HSPs) & $\begin{array}{l}\text { Increased production and activity of molecular chaperones Hsp 60, 70, and } 90 \\
\text { to ensure correct digestion of degraded proteins and folding of new proteins } \\
\text { within the Endoplasmic Reticulum. Core component of the Unfolded Protein } \\
\text { Response }\end{array}$ & $\begin{array}{l}\text { Leggat et al., 2011; Rosic et al., 2011; Seveso } \\
\text { et al., 2014, } 2016\end{array}$ \\
\hline Enzymatic antioxidants & $\begin{array}{l}\text { Increased production and activity of SOD, APX, CAT, GR, and DMSO (see } \\
\text { Table 1) in order to counter the accumulation of oxygen radicals and prevent } \\
\text { cellular damage }\end{array}$ & $\begin{array}{l}\text { Krueger et al., 2014, 2015; Roberty et al., } \\
\text { 2015; Gardner et al., } 2017\end{array}$ \\
\hline Non-enzymatic antioxidants & $\begin{array}{l}\text { Increased genetic expression of cytochrome P450 and heat shock proteins, } \\
\text { with putative antioxidant properties }\end{array}$ & Rosic et al., 2010 \\
\hline $\begin{array}{l}\text { D1 repair and de novo } \\
\text { synthesis (symbiont) }\end{array}$ & $\begin{array}{l}\text { Increased in situ repair and de novo synthesis of D1 reaction centre proteins } \\
\text { that are damaged during photoinhibition by combined high light and high } \\
\text { temperature }\end{array}$ & $\begin{array}{l}\text { Takahashi et al., 2008, 2009, 2013; Hill et al., } \\
2011\end{array}$ \\
\hline Lipid membrane composition & $\begin{array}{l}\text { Composition shift toward higher saturation of Polyunsaturated Fatty Acids } \\
\text { (PUFAs) in the lipid membrane, to increase resistance to oxidative stress }\end{array}$ & Tchernov et al., 2004 \\
\hline $\begin{array}{l}\text { Photoprotective proteins and } \\
\text { MAAs }\end{array}$ & $\begin{array}{l}\text { Higher bio-synthesis of mycosporine-like amino acids (MAAs) and } \\
\text { photoprotective proteins in both coral host and algal symbiont }\end{array}$ & $\begin{array}{l}\text { Dove, 2004; Banaszak et al., 2006; Dove and } \\
\text { Hoegh-Guldberg, 2006; Rosic and Dove, } 2011\end{array}$ \\
\hline $\begin{array}{l}\text { Non-photochemical quenching } \\
\text { (symbiont) }\end{array}$ & $\begin{array}{l}\text { More de-epoxidation of xanthophyll pigments in order to dissipate excess } \\
\text { excitation energy }\end{array}$ & Hill et al., 2005; Middlebrook et al., 2010 \\
\hline Unfolded protein response & $\begin{array}{l}\text { Generalized response to the accumulation of degraded proteins. Acts to slow } \\
\text { and minimize errors in protein synthesis }\end{array}$ & $\begin{array}{l}\text { Walter and Ron, 2011; Ruiz-Jones and } \\
\text { Palumbi, 2017; Traylor-Knowles et al., } 2017\end{array}$ \\
\hline
\end{tabular}

See Table 1 for antioxidant abbreviations.

or light stress-induced symbiosis breakdown. The prevailing theory around the primary cause of coral bleaching is the production of ROS following heat induced impairment to photosynthesis within the symbiont (Table 1; Jones et al., 1998; Takahashi et al., 2009), although mitochondrial damage in both host and symbiont has also been implicated (Dunn et al., 2012). ROS are natural products of the series of redox reactions that form electron transport chains in both photosynthesis and respiration (Eberhard et al., 2008; Murphy, 2009). There are numerous ROS species generated through multiple molecular pathways that have the potential to disrupt cellular homeostasis through the oxidation of lipids, proteins and DNA (Table 1; Lesser, 1997; Jones et al., 1998). As such, cells have evolved natural antioxidant mechanisms to neutralize ROS and prevent oxidative stress (see Table 4). For example, during thermal stress, there is an increased production and activity of antioxidants in the symbiotic algae, in response to the accumulation of ROS that arises from the disruption to electron transport (Krueger et al., 2014, 2015; Roberty et al., 2015).

Increased temperature is also characterized by higher frequencies of apoptosis (cell death) and the upregulation of cellular apoptotic pathways in the coral animal. Apoptosis is a highly conserved evolutionary response (Quistad et al., 2014; Moya et al., 2016) that has evolved to remove damaged cells and prevent the further damage (Elmore, 2007). This is in contrast to uncontrolled cell necrosis in which cells degrade, swell and burst, to the detriment of neighboring cells (Elmore, 2007). Apoptosis has been observed to occur in both coral and algal cells during the very early stages of thermal stress (Dunn et al., 2004; Ainsworth et al., 2008, 2011; Strychar and Sammarco, 2009) and initially is localized to the gastrodermal cells that contain symbionts, suggesting that this is triggered through the initial photo-bleaching stage of the bleaching process (Ainsworth et al., 2008, 2011). While apoptosis is a stress response to cellular damage that results in the removal of host cells, this process increases the potential of the individual coral colony to survive by maximizing resources for the surviving cells and removing sources of ROS (Ainsworth et al., 2011; Tchernov et al., 2011; Kvitt et al., 2016).

Upregulation of antioxidants, the apoptotic pathway and other stress responses, such as increased heat shock protein production for protein repair and replacement (Table 4; Walter and Ron, 2011; Seveso et al., 2014; Ruiz-Jones and Palumbi, 2017), are evolutionary mechanisms designed to increased colony survival during thermal stress. Together with species-specific characteristics, such as tissue thickness, skeletal morphology and feeding behavior, these mechanisms drive interspecific variability in coral stress responses (through acclimatization) as heat stress accumulates. Therefore, in canonical bleaching events where summertime thermal stress drives coral bleaching after several weeks to months, the meta-organism's thermal tolerance is directly determined by the cellular processes and speciesspecific traits that underpin inherent thermal tolerance and the potential for the induction of further protective mechanisms (i.e., acclimatization) (Coles and Brown, 2003; Bowler, 2005). These processes ultimately drive differential interspecific responses to thermal stress and thus determine how coral communities are affected by coral bleaching events. Under the extreme conditions of summertime MHW hotspots, this relationship between temperature stress and bleaching susceptibility becomes less clear as the severity undermines the capacity for acclimatization. When exposed to sufficiently large and rapid onset temperature anomalies, the induction of acclamatory mechanisms is bypassed or impaired and inherent thermal tolerance is overwhelmed. The hosts' molecular and cellular responses to damage are either inhibited or insufficient to repair the extent of damage as it 
occurs within the cells. For example, a uniformly sharp decline in the activity of the antioxidant enzymes, glutathione reductase (GR) and superoxide dismutase (SOD), was described following exposure of zooxanthellae to $33^{\circ} \mathrm{C}$ for 6 days, irrespective of whether the symbiont was considered thermally tolerant or susceptible (Krueger et al., 2014). A similar thermal exposure $\left(33.5^{\circ} \mathrm{C}\right.$ for 6 days) of the zooxanthellate sea anemone Aiptasia also resulted in a reduced frequency of apoptosis but more frequent necrosis in both host and symbiont (Dunn et al., 2004). In the coral Seriatopora caliendrum, a collapse in the activity of heat shock protein 60 was seen in just $18 \mathrm{~h}$ after a sudden temperature increase to $33^{\circ} \mathrm{C}$ (Seveso et al., 2016). This inhibition of the apoptotic protective mechanism, in conjunction with reduced antioxidation and cellular repair, indicates damage to, or overwhelming of, cellular acclimatory mechanisms and the rapid coral mortality of species with both high and low tolerance indicates a failure of protective mechanisms to safeguard the animal against heat-induced cell death. This scenario has recently been observed in a number of locations where coral mortality during extreme thermal stress is unrelated to historical community responses (Schoepf et al., 2015; Baird et al., 2017; DeCarlo et al., 2017; Hoogenboom et al., 2017; Le Nohaïc et al., 2017). This evidence demonstrates that under severe and rapid heating associated with MHW hotspots, the response of the coral animal is distinct from how we currently define coral bleaching and associated mortality.

\section{POST-MORTALITY PROCESSES FOLLOWING MHWS}

Given that rapid and extensive cell (and thus colony) mortality is a direct consequence of extreme thermal stress and occurs in a distinct fashion, this suggests that post-mortality processes on coral colonies may also be distinct. This is especially the case when thermal stress conditions persist after rapid coral mortality, which is likely given the short time frames in which MHW hotspots can drive ecological degradation. Recent evidence presented by Leggat et al. (2019) demonstrates that extreme, rapid onset thermal stress, and the associated heatinduced mortality, together with local oceanographic conditions (doldrums, low water flow, and high light intensity) promote rapid microbial bioerosion of coral skeletons by phototrophic microbes, resulting in a degradation of reef structural frameworks at rates hereto unprecedented (Table 5). The cause is the microbial bloom formation of endolithic microborers, which reside within the skeletons of living corals skeleton and colonize newly exposed substrates (i.e., recently dead corals). This study represents the first time that the effect of coral mortality and thermal stress upon microbial bioerosion has been investigated, and suggests that MHW hotspots have an effect upon the physical reef structure, as well as the biological community.

Endolithic phototrophic microbes are arguably the second most significant bioeroders on coral reefs, after parrotfish (Carreiro-Silva et al., 2005; Perry et al., 2014). Knowledge of this microbial community is extremely limited, but it is already recognized as able to undermine structural stability over longer time frames (Tribollet, 2008a; Tribollet and Golubic, 2011; Silbiger et al., 2015; Couch et al., 2017) and is considered an important driver of reef-wide shifts toward net erosion (Perry and Morgan, 2017). The evidence presented by Leggat et al. (2019) changes how we currently understand the short- and long-term consequences of thermal stress on a reef, though the processes underlying this outcome remain to be elucidated (Figure 2). Studies over longer time frames have shown that increased light, temperature, $p \mathrm{CO}_{2}$ and nutrient load accelerate rates of microbial bioerosion (Tribollet and Golubic, 2005; CarreiroSilva et al., 2009; Tribollet et al., 2009; Reyes-Nivia et al., 2013), through promoting the growth of primarily endolithic eukaryotic algae. The rapid mortality during a MHW hotspot represents a rapid shift in conditions within the otherwise stable endolithic

TABLE 5 | Maximum rates of microbioerosion reported in the literature, in different substrates and under a variety of environmental or experimental conditions (Leggat et al., 2019).

\begin{tabular}{|c|c|c|c|}
\hline Substrate & Environmental conditions & Rate $\left(\mathrm{g} \mathrm{CaCO}_{3} \mathrm{~m}^{-2}\right.$ month $\left.^{-1}\right)$ & Source \\
\hline Mollusc sediment & Ambient, reef lagoon & 29.2 & Tudhope and Risk, 1985 \\
\hline Mollusc shell (Strombus gigas) & Experimental inorganic nutrient enrichment, in situ & 37.6 & Carreiro-Silva et al., 2005 \\
\hline Mollusc shell (Strombus gigas) & Experimental inorganic nutrient enrichment, in situ & 33.2 & Carreiro-Silva et al., 2009 \\
\hline Mollusc shell (Strombus gigas) & Experimental inorganic nutrient enrichment, in situ & 49.4 & Carreiro-Silva et al., 2012 \\
\hline Mollusc shell (Tricadna sp.) & Inshore reef subject to terrestrial discharge (river) & 11.4 & Mwachireya et al., 2018 \\
\hline Coral block (Porites sp.) & Volcanically acidified reef $\left(\mathrm{pCO}_{2}=502 \mu \mathrm{atm}\right)$ & 126.6 & Enochs et al., 2016 \\
\hline Coral block (Porites sp.) & Oligotrophic offshore reef (Osprey Reef) & 111.7 & Tribollet et al., 2002 \\
\hline Coral block (Porites sp.) & Oligotrophic offshore reef (Osprey Reef) & 112.5 & Tribollet, 2008a \\
\hline Coral block (Porites sp.) & $\begin{array}{l}\text { Experimental } p \mathrm{CO}_{2} \text { increase, ex situ }\left(\mathrm{pCO}_{2}=750\right. \\
\mu \text { atm })\end{array}$ & 39.0 & Tribollet et al., 2009 \\
\hline Coral block (Porites sp.) & Oligotrophic offshore reef (Osprey Reef) & 116.7 & Tribollet and Golubic, 2005 \\
\hline Micritic limestone & Ambient, reef lagoon & 43.3 & Vogel et al., 2000 \\
\hline Coral block (Porites cylindrica) & $\begin{array}{l}\text { Experimental } \mathrm{pCO}_{2}+\text { temperature increase, ex situ } \\
\left(\mathrm{pCO}_{2}=1010 \mu \mathrm{atm} \text {; temp }=\text { control }+4^{\circ} \mathrm{C}\right)\end{array}$ & 239.6 & Reyes-Nivia et al., 2013 \\
\hline $\begin{array}{l}\text { Coral colony fragment } \\
\text { (Acropora aspera) }\end{array}$ & $\begin{array}{l}\text { Experimental, marine heatwave induced mortality } \\
(\mathrm{DHW}>8)\end{array}$ & 1584 & Leggat et al., 2019 \\
\hline
\end{tabular}




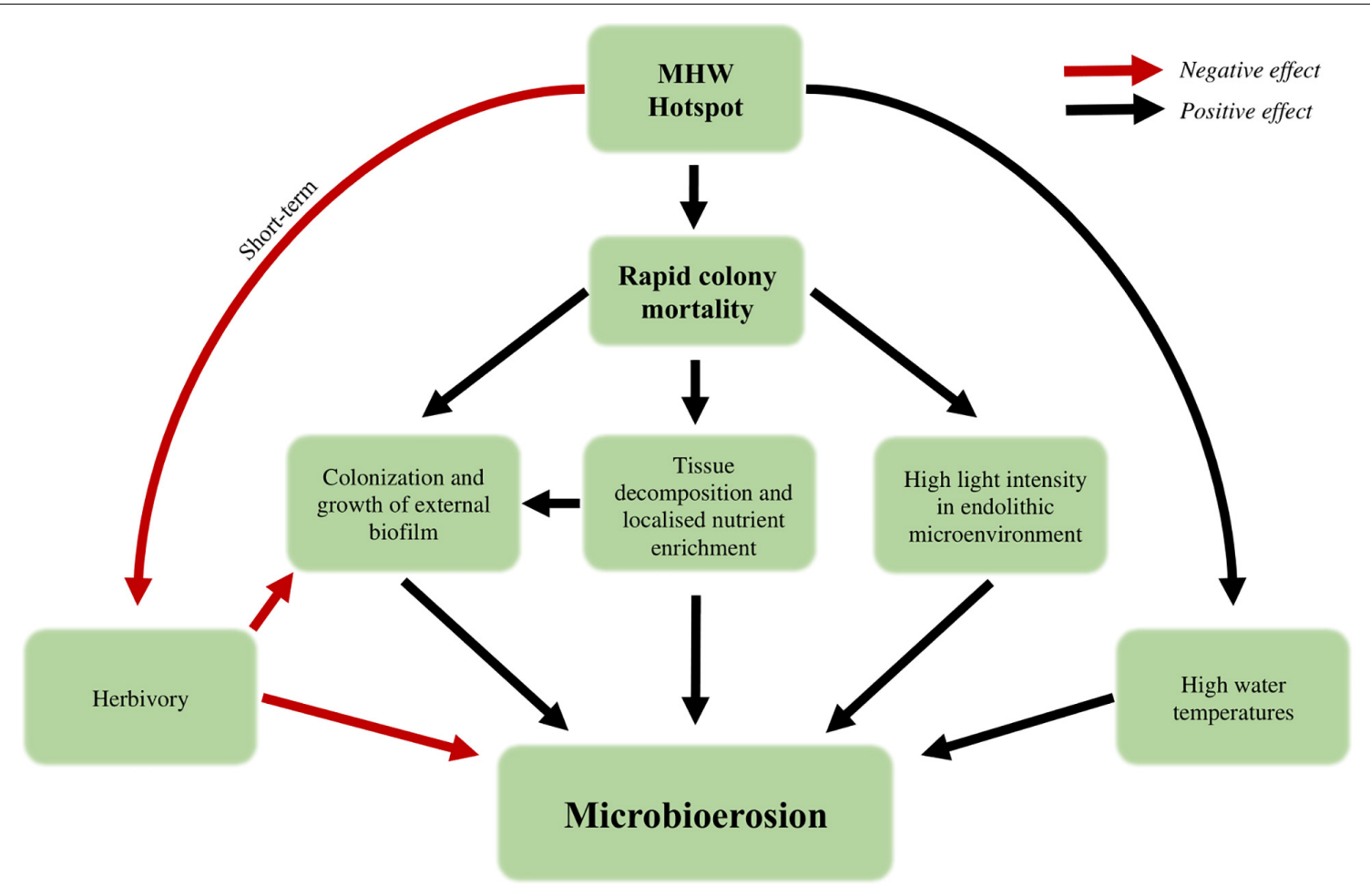

FIGURE 2 | Theoretical combination of abiotic and biotic changes during a marine heatwave that favor accelerated bioerosion by microbial endoliths.

microenvironment, changes to which the resident microbes can rapidly acclimatize (Fine et al., 2004, 2005). Increased light intensity, due to the loss of coral symbionts that otherwise attenuate incoming irradiance, high water temperatures that drive faster metabolism and growth, and a higher availability of nitrogen through rapid tissue decomposition that supports greater biomass, are all likely to play roles in driving increased microbial bioerosion (Figure 2).

While there is evidence of MHW hotspots accelerating microbioerosion, and a theoretical framework to support this, what remains unclear is how microbioerosion is influenced by less severe and/or rapid coral bleaching and mortality events. During a canonical coral bleaching/mortality event, ecological degradation evolves over a longer time frame compared to MHW hotspot driven mass mortality as described above. This has a number of possible implications for the process of microbioerosion. Firstly, as coral mortality and the subsequent bloom formation of phototrophic microbes is spatially more patchy, these patches of algal overgrowth can more easily be grazed down by reef herbivores. On the other hand, if a large population of corals dies within a very short time frame then the ensuing growth of microbial algae over a large area could exceed rates of herbivory. This is especially true of endolithic algae already living within coral skeletons (as opposed to colonizers) that only excavating herbivores, such as parrotfish, are able to graze upon (Clements et al., 2017).

Secondly, given that canonical coral mortality events tend to occur toward the end of the summer season after months of heat accumulation and stress, algal microborers are exposed to warm, bright summer conditions for less time before the season ends. In contrast, if a MHW hotspot causes mass mortality in the early summer months [e.g., Weeks et al. (2008)] then microborers have a full summer of ideal conditions for growth and bioerosion. We emphasize here that the accelerated microbioerosion associated with MHW hotspots is, as we currently understand it, an acute effect. It is unknown whether these accelerated rates persist in the long term, though the effects of rapid degradation in reducing structural complexity are likely to persist given that this physical characteristic of coral reefs is otherwise relatively stable over time (Graham et al., 2015).

Finally, the extremity of physical conditions during MHW hotspots that drive rapid ecological degradation would increase the metabolism and growth of phototrophic microbes more so than the comparatively milder conditions of canonical coral mortality events. Together, these characteristics of MHW hotspot driven mass mortality suggest that rapid erosion of the physical reef framework is likely to be a product of extreme thermal stress events, but further research into the effects of thermal stress and coral mortality upon microbial bioerosion is needed to support this.

Given the negative effect of MHW hotspots upon reef structural complexity, we can expect this acute process to affect the long term recovery of affected coral reefs. In our current understanding of coral bleaching events, the recovery of surviving bleached corals depends on the replenishment of symbionts within the intact host, and the re-growth and propagation of these "winners" drives reef-scale recovery. Following events resulting in mass mortality, reef recovery 
depends upon successful larval recruitment (Idjadi et al., 2006; Gilmour et al., 2013; Hock et al., 2017), and the suppression of algal competition (Edmunds and Carpenter, 2001; Bellwood et al., 2006; Hock et al., 2017). These factors together influence the likelihood of an ecosystem-wide phase shift (Table 1) toward an algal reef and an alteration to ecosystem function (Graham et al., 2011, 2015; Stuart-Smith et al., 2018).

An important component of both successful recruitment and the suppression of algal competition is the structural complexity of the reef (Vergés et al., 2011; Coker et al., 2012; Harris et al., 2018). For example, topographic complexity has been shown to support higher abundances of settled larvae by presenting more opportunity for refuge from predation (Coker et al., 2012; Graham and Nash, 2013; Rogers et al., 2014). Similarly, herbivory is a core driver of reef recovery (Bellwood et al., 2006; Graham et al., 2011) and is promoted by structural complexity (Vergés et al., 2011). Indeed, a loss of structural complexity can effectively predict the probability of a coral-algal phase shift following mass mortality (Graham et al., 2015), as well as the long term recovery trajectory of coral populations (Robinson et al., 2019a) in part due to concurrent changes in the composition of fish communities (Graham et al., 2015; Robinson et al., 2019b) and the level of larval recruitment (Gilmour et al., 2013; Graham et al., 2015).

The effect of MHW hotspots upon herbivore biomass and abundance likely depends upon the examined functional group and the time frame during which we consider changes. In the short term, MHWs have been observed to result in the mass mortality of benthic herbivores, which can be significant grazers of turf and macroalgae (Garrabou et al., 2009; Wernberg et al., 2012). A key example of this is the 2011 MHW in Western Australia which caused, in one location, 99\% mortality in a herbivorous benthic gastropod (Smale et al., 2017). Herbivorous fish often increase in abundance in the months and years following thermal stress events (Garrabou et al., 2009; Wernberg et al., 2012). However, given the short time frames in which algal overgrowth and coral-algal phase shifts are occuring during $\mathrm{MHW}$ hotspots (<2 months) (DeCarlo et al., 2017; Hughes et al., 2017), this effect is either delayed with respect to the phototrophic microbial bloom or insufficient to prevent rapid phase shifts. In fact, in the long term, overall bioerosion may increase in the months following a MHW hotspot due to a higher relative and absolute abundance of excavating fish herbivores (Pratchett et al., 2008; Stuart-Smith et al., 2018) which can be the biggest source of bioerosion in reef environments (Carreiro-Silva et al., 2005; Perry et al., 2014). The threeway interaction between herbivory, microbioerosion and $\mathrm{MHW}$ hotspots needs further investigation but we hypothesize that short-term increases in microbioerosion may then be followed by higher macrobioerosion by excavating fish. While a number

\section{REFERENCES}

Ainsworth, T. D., Hoegh-Guldberg, O., Heron, S. F., Skirving, W. J., and Leggat, W. (2008). Early cellular changes are indicators of pre-bleaching thermal stress in the coral host. J. Exp. Mar. Biol. Ecol. 364, 63-71. doi: 10.1016/j.jembe.2008.06.032 of questions remain to be resolved regarding this process, these studies highlight the potential for MHW hotspots to impair long term recovery by leading to a rapid degradation of structural complexity (Figure 2).

\section{CONCLUSION}

Our current understanding of the responses of corals to thermal stress, and our predictions of how they will respond in the future are based upon historic bleaching events under which coral and reef degradation is progressive as stress accumulates. However, the emergence of summertime $\mathrm{MHW}$ hotspots, the extreme nature of which have no historical counterparts, fundamentally changes how we understand the consequences of climate change in regards to corals reefs worldwide. They result in distinct molecular, cellular and microbial responses, and drive rapid large-scale coral mortality and decay in atypical timeframes. These devastating impacts are occurring irrespective of historical temperature and bleaching regimes, and the long-term ecological consequences of these large-scale mortality events are only now being documented. As such we propose that acute, intense summertime MHW hotspots need to be recognized as a new category of thermal stress event in coral reefs, distinct from the canonical DHW scale that has historically been used to describe bleaching-induced mortality in recent decades.

\section{AUTHOR CONTRIBUTIONS}

AF, TA, SF, and WL developed the concept for the manuscript. $\mathrm{AF}$ wrote the original draft of the review which was edited and expanded upon by TA, SF, and WL.

\section{FUNDING}

This research and the authors herein were supported by an Australian Research Council Discovery Project Grant (DP180103199).

\section{ACKNOWLEDGMENTS}

The authors would like to acknowledge Prof. Silvia Frisia and Assoc. Prof. Danielle Verdon-Kidd for comments on the original manuscript. The scientific results and conclusions, as well as any views or opinions expressed herein, are those of the author(s) and do not necessarily reflect the views of NOAA or the Department of Commerce.

Ainsworth, T. D., Wasmund, K., Ukani, L., Seneca, F., Yellowlees, D., Miller, D., et al. (2011). Defining the tipping point: a complex cellular life/death balance in corals in response to stress. Sci. Rep. 1:160. doi: 10.1038/srep0 0160

Anthony, K. R. N., Hoogenboom, M. O., Maynard, J. A., Grottoli, A. G., and Middlebrook, R. (2009). Energetics approach to predicting mortality risk from 
environmental stress: a case study of coral bleaching. Funct. Ecol. 23, 539-550. doi: 10.1111/j.1365-2435.2008.01531.x

Bainbridge, S. J. (2017). Temperature and light patterns at four reefs along the Great Barrier Reef during the 2015-2016 austral summer: understanding patterns of observed coral bleaching. J. Operat. Oceanogr. 10, 16-29. doi: 10.1080/1755876x.2017.1290863

Baird, A. H., Bhagooli, R., Ralph, P. J., and Takahashi, S. (2009). Coral bleaching: the role of the host. Trends Ecol. Evol. 24, 16-20. doi: 10.1016/j.tree.2008.09.005

Baird, A. H., Keith, S. A., Woolsey, E., Yoshida, R., and Naruse, T. (2017). Rapid coral mortality following doldrums-like conditions on Iriomote, Japan. F1000Research 6:1728. doi: 10.12688/f1000research.12 660.2

Baird, A. H., and Marshall, P. A. (2002). Mortality, growth and reproduction in scleractinian corals following bleaching on the Great Barrier Reef. Mar. Ecol. Prog. Ser. 237, 133-141. doi: 10.3354/meps237133

Banaszak, A. T., Barba Santos, M. G., Lajeunesse, T. C., and Lesser, M. P. (2006). The distribution of mycosporine-like amino acids (MAAs) and the phylogenetic identity of symbiotic dinoflagellates in cnidarian hosts from the Mexican Caribbean. J. Exp. Mar. Biol. Ecol. 337, 131-146. doi: 10.1016/j.jembe.2006. 06.014

Bellwood, D. R., Hughes, T. P., and Hoey, A. S. (2006). Sleeping functional group drives coral-reef recovery. Curr. Biol. 16, 2434-2439. doi: 10.1016/j.cub.2006. 10.030

Berkelmans, R., De'ath, G., Kininmonth, S., and Skirving, W. J. (2004). A comparison of the 1998 and 2002 coral bleaching events on the Great Barrier Reef: spatial correlation, patterns, and predictions. Coral Reefs 23, 74-83. doi: 10.1007/s00338-003-0353-y

Berkelmans, R., and Van Oppen, M. J. H. (2006). The role of zooxanthellae in the thermal tolerance of corals: a 'nugget of hope' for coral reefs in an era of climate change. Proc. R. Soc. B Biol. Sci. 273, 2305-2312. doi: 10.1098/rspb.2006.3567

Berkelmans, R., and Willis, B. (1999). Seasonal and local spatial patterns in the upper thermal limits of corals on the inshore Central Great Barrier Reef. Coral Reefs 18, 219-228. doi: 10.1007/s003380050186

Bowler, K. (2005). Acclimation, heat shock and hardening. J. Therm. Biol. 30, 125-130. doi: 10.1016/j.jtherbio.2004.09.001

Brown, B. E., Dunne, R. P., Phongsuwan, N., Patchim, L., and Hawkridge, J. M. (2014). The reef coral Goniastrea aspera: a 'winner' becomes a 'loser' during a severe bleaching event in Thailand. Coral Reefs 33, 395-401. doi: 10.1007/s00338-013-1120-3

Burt, J. A., Paparella, F., Al-Mansoori, N., Al-Mansoori, A., and Al-Jailani, H. (2019). Causes and consequences of the 2017 coral bleaching event in the southern Persian/Arabian Gulf. Coral Reefs 38, 567-589. doi: 10.1007/s00338019-01767-y

Camp, E. F., Schoepf, V., Mumby, P. J., Hardtke, L. A., Rodolfo-Metalpa, R., Smith, D. J., et al. (2018). The Future of coral reefs subject to rapid climate change: lessons from natural extreme environments. Front. Mar. Sci. 5:4. doi: 10.3389/fmars.2018.00004

Carreiro-Silva, M., Kiene, W. E., Golubic, S., and Mcclanahan, T. R. (2012). Phosphorus and nitrogen effects on microbial euendolithic communities and their bioerosion rates. Mar. Pollut. Bull. 64, 602-613. doi: 10.1016/j.marpolbul. 2011.12.013

Carreiro-Silva, M., Mcclanahan, T. R., and Kiene, W. E. (2005). The role of inorganic nutrients and herbivory in controlling microbioerosion of carbonate substratum. Coral Reefs 24, 214-221. doi: 10.1007/s00338-004-0445-3

Carreiro-Silva, M., Mcclanahan, T. R., and Kiene, W. E. (2009). Effects of inorganic nutrients and organic matter on microbial euendolithic community composition and microbioerosion rates. Mar. Ecol. Prog. Ser. 392, 1-15. doi: 10.3354/meps08251

Carrigan, A. D., and Puotinen, M. L. (2011). Assessing the potential for tropical cyclone induced sea surface cooling to reduce thermal stress on the world's coral reefs. Geophys. Res. Lett. 38, 1-5. doi: 10.3354/meps08251

Clements, K. D., German, D. P., Piché, J., Tribollet, A., and Choat, J. H. (2017). Integrating ecological roles and trophic diversification on coral reefs: multiple lines of evidence identify parrotfishes as microphages. Biol. J. Linn. Soc. 120, 729-751.

Coker, D. J., Graham, N. A. J., and Pratchett, M. S. (2012). Interactive effects of live coral and structural complexity on the recruitment of reef fishes. Coral Reefs 31, 919-927. doi: 10.1007/s00338-012-0920-1
Coles, S. L., and Brown, B. E. (2003). Coral bleaching - capacity for acclimatization and adaptation. Adv. Mar. Biol. 46, 183-223. doi: 10.1016/s0065-2881(03) 46004-5

Couch, C. S., Burns, J. H. R., Liu, G., Steward, K., Gutlay, T. N., Kenyon, J., et al. (2017). Mass coral bleaching due to unprecedented marine heatwave in Papahanaumokuakea Marine National Monument (Northwestern Hawaiian Islands). PLoS One 12:e0185121. doi: 10.1371/journal.pone.0185121

Davis, K. A., Lentz, S. J., Pineda, J., Farrar, J. T., Starczak, V. R., and Churchill, J. H. (2011). Observations of the thermal environment on Red Sea platform reefs: a heat budget analysis. Coral Reefs 30, 25-36. doi: 10.1007/s00338-0110740-8

DeCarlo, T. M., Cohen, A. L., Wong, G. T., Davis, K. A., Lohmann, P., and Soong, K. (2017). Mass coral mortality under local amplification of 2 ? ocean warming. Sci. Rep. 7:44586. doi: 10.1038/srep44586

Diaz-Pulido, G., Mccook, L. J., Dove, S., Berkelmans, R., Roff, G., Kline, D. I., et al. (2009). Doom and boom on a resilient reef: climate change, algal overgrowth and coral recovery. PLoS One 4:e5239. doi: 10.1371/journal.pone.0005239

DiMassa, D. D., Heron, M. L., Mantovanelli, A., Heron, S. F., and Steinberg, C. (2010). "Can vertical mixing from turbulent kinetic energy mitigate coral bleaching? An application of high frequency ocean radar," in Proceedings of the OCEANS'10 IEEE Conference, (Sydney, NSW: IEEE), 1-5.

Donner, S. D., Skirving, W. J., Little, C. M., Oppenheimer, M., and HoeghGuldberg, O. V. E. (2005). Global assessment of coral bleaching and required rates of adaptation under climate change. Glob. Change Biol. 11, 2251-2265. doi: $10.1111 / j .1365-2486.2005 .01073 . x$

Dove, S. (2004). Scleractinian corals with photoprotective host pigments are hypersensitive to thermal bleaching. Mar. Ecol. Prog. Ser. 272, 99-116. doi: $10.3354 /$ meps 272099

Dove, S. G., and Hoegh-Guldberg, O. (2006). "The cell physiology of coral bleaching," in Coral Reefs and Climate Change: Science and Management, eds J. T. Phinney, O. Hoegh-Guldberg, J. Kleypas, J. W. Skirving, and A. E. Strong (Washington, DC: American Geophysical Union), 55-71.

Dunn, S. R., Pernice, M., Green, K., Hoegh-Guldberg, O., and Dove, S. G. (2012). Thermal stress promotes host mitochondrial degradation in symbiotic cnidarians: are the batteries of the reef going to run out? PLoS One 7:e39024. doi: 10.1371/journal.pone.0039024

Dunn, S. R., Thomason, J. C., Le Tissier, M. D. A., and Bythell, J. C. (2004). Heat stress induces different forms of cell death in sea anemones and their endosymbiotic algae depending on temperature and duration. Cell Death Differ. $11,213-222$.

Eakin, C., Liu, G., Gomez, A., De La Cour, J., Heron, S., Skirving, W., et al. (2017). Ding, dong, the witch is dead (?) — three years of global coral bleaching 2014-2017. Reef Encount. 32, 33-38.

Eberhard, S., Finazzi, G., and Wollman, F.-A. (2008). The dynamics of photosynthesis. Annu. Rev. Genet. 42, 463-515.

Edmunds, P. J., and Carpenter, R. C. (2001). Recovery of Diadema antillarum reduces macroalgal cover and increases abundance of juvenile corals on a Caribbean reef. Proc. Natl. Acad. Sci. U.S.A. 98, 5067-5071. doi: 10.1073/pnas. 071524598

Elmore, S. (2007). Apoptosis: a review of programmed cell death. Toxicol. Pathol. 35, 495-516.

Enochs, I. C., Manzello, D. P., Tribollet, A., Valentino, L., Kolodziej, G., Donham, E. M., et al. (2016). Elevated colonization of microborers at a volcanically acidified Coral Reef. PLoS One 11:e0159818.doi:10.1371/journal.pone.015 9818

Fine, M., Meroz-Fine, E., and Hoegh-Guldberg, O. (2005). Tolerance of endolithic algae to elevated temperature and light in the coral Montipora monasteriata from the southern Great Barrier Reef. J. Exp. Biol. 208, 75-81. doi: 10.1242/ jeb.01381

Fine, M., Steindler, L., and Loya, Y. (2004). Endolithic algae photoacclimate to increased irradiance during coral bleaching. Mar. Freshw. Res. 55, 115-121.

Fitt, W. K., Gates, R. D., Hoegh-Guldberg, O., Bythell, J. C., Jatkar, A., Grottoli, A. G., et al. (2009). Response of two species of Indo-Pacific corals, Porites cylindrica and Stylophora pistillata, to short-term thermal stress: the host does matter in determining the tolerance of corals to bleaching. J. Exp. Mar. Biol. Ecol. 373, 102-110. doi: 10.1016/j.jembe.2009.03.011

Fitt, W. K., Mcfarland, F., Warner, M. E., and Chilcoat, G. C. (2000). Seasonal patterns of tissue biomass and densities of symbiotic dinoflagellates in reef 
corals and relation to coral bleaching. Limnol. Oceanogr. 45, 677-685. doi: $10.4319 / 10.2000 .45 .3 .0677$

Fitt, W. K., and Warner, M. E. (1995). Bleaching patterns of four species of caribbean reef corals. Biol. Bull. 189, 298-307. doi: 10.2307/154 2147

Frolicher, T. L., and Laufkotter, C. (2018). Emerging risks from marine heat waves. Nat. Commun. 9:650. doi: 10.1038/s41467-018-03163-6

Gardner, S. G., Raina, J.-B., Nitschke, M. R., Nielsen, D. A., Stat, M., Motti, C. A., et al. (2017). A multi-trait systems approach reveals a response cascade to bleaching in corals. BMC Biol. 15:117. doi: 10.1186/s12915-017-0459-2

Garrabou, J., Coma, R., Bensoussan, N., Bally, M., Chevaldonné, P., Cigliano, M., et al. (2009). Mass mortality in northwestern Mediterranean rocky benthic communities: effects of the 2003 heat wave. Glob. Change Biol. 15, 1090-1103. doi: $10.1111 / j .1365-2486.2008 .01823 . x$

Gates, R. D., and Edmunds, P. J. (1999). The physiological mechanisms of acclimatization in tropical reef corals. Am. Zool. 39, 30-43. doi: 10.1093/icb/ 39.1.30

Gilmour, J. P., Cook, K. L., Ryan, N. M., Puotinen, M. L., Green, R. H., Shedrawi, G., et al. (2019). The state of Western Australia's coral reefs. Coral Reefs 38, 651-667. doi: 10.1007/s00338-019-01795-8

Gilmour, J. P., Smith, L. D., Heyward, A. J., Baird, A. H., and Pratchett, M. S. (2013). Recovery of an isolated coral reef system following severe disturbance. Science 340, 69-71. doi: 10.1126/science.1232310

Graham, N. A., Jennings, S., Macneil, M. A., Mouillot, D., and Wilson, S. K. (2015). Predicting climate-driven regime shifts versus rebound potential in coral reefs. Nature 518, 94-97. doi: 10.1038/nature14140

Graham, N. A. J., and Nash, K. L. (2013). The importance of structural complexity in coral reef ecosystems. Coral Reefs 32, 315-326. doi: 10.1007/s00338-0120984-y

Graham, N. A. J., Nash, K. L., and Kool, J. T. (2011). Coral reef recovery dynamics in a changing world. Coral Reefs 30, 283-294. doi: 10.1007/s00338-010$0717-\mathrm{z}$

Grant, A. L. M., and Belcher, S. E. (2011). Wind-driven mixing below the Oceanic mixed layer. J. Phys. Oceanogr. 41, 1556-1575. doi: 10.1175/jpo-d-10-05020.1

Great Barrier Reef Marine Park Authority, (2016). Interim Report: 2016 Coral Bleaching Event on the Great Barrier Reef. Townsville, QLD: Great Barrier Reef Marine Park Authority.

Grottoli, A. G., Rodrigues, L. J., and Palardy, J. E. (2006). Heterotrophic plasticity and resilience in bleached corals. Nature 440, 1186-1189. doi: 10.1038/ nature 04565

Grottoli, A. G., Tchernov, D., and Winters, G. (2017). Physiological and biogeochemical responses of super-corals to thermal stress from the Northern Gulf of Aqaba, Red sea. Front. Mar. Sci. 4:215. doi: 10.3389/fmars.2017.00215

Harris, D. L., Rovere, A., Casella, E., Power, H., Canavesio, R., Collin, A., et al. (2018). Coral reef structural complexity provides important coastal protection from waves under rising sea levels. Sci. Adv. 4:eaao4350. doi: 10.1126/sciadv. aao4350

Heron, S. F., Liu, G., Eakin, C. M., Skirving, W. J., Muller-Karger, F. E., Vega-Rodriguez, M., et al. (2014). Climatology Development for NOAA Coral Reef Watchs 5-km Product Suite. NOAA Technical Report NESDIS 145. Washington, DC: U.S. Department Of Commerce.

Heron, S. F., Maynard, J. A., Van Hooidonk, R., and Eakin, C. M. (2016). Warming trends and bleaching stress of the world's coral reefs 1985-2012. Sci. Rep. 6:38402. doi: $10.1038 /$ srep38402

Heron, S. F., Willis, B. L., Skirving, W. J., Eakin, C. M., Page, C. A., and Miller, I. R. (2010). Summer hot snaps and winter conditions: modelling white syndrome outbreaks on Great Barrier Reef corals. PLoS One 5:e12210. doi: 10.1371/ journal.pone. 0012210

Hill, R., Brown, C. M., Dezeeuw, K., Campbell, D. A., and Ralph, P. J. (2011). Increased rate of D1 repair in coral symbionts during bleaching is insufficient to counter accelerated photo-inactivation. Limnol. Oceanogr. 56, 139-146. doi: 10.4319/lo.2011.56.1.0139

Hill, R., Frankart, C., and Ralph, P. J. (2005). Impact of bleaching conditions on the components of non-photochemical quenching in the zooxanthellae of a coral. J. Exp. Mar. Biol. Ecol. 322, 83-92. doi: 10.1016/j.jembe.2005.02.011

Hobday, A. J., Alexander, L. V., Perkins, S. E., Smale, D. A., Straub, S. C., Oliver, E. C. J., et al. (2016). A hierarchical approach to defining marine heatwaves. Prog. Oceanogr. 141, 227-238. doi: 10.1016/j.pocean.2015.12.014
Hobday, A. J., Oliver, E. C., Gupta, A. S., Benthuysen, J. A., Burrows, M. T., Donat, M. G., et al. (2018). Categorizing and naming marine heatwaves. Oceanography $31,162-173$.

Hock, K., Wolff, N. H., Ortiz, J. C., Condie, S. A., Anthony, K. R. N., Blackwell, P. G., et al. (2017). Connectivity and systemic resilience of the Great Barrier Reef. PLoS Biol. 15:e2003355. doi: 10.1371/journal.pbio.2003355

Hoegh-Guldberg, O. (1999). Climate change, coral bleaching and the future of the world's coral reefs. Mar. Freshw. Res. 50, 839-866.

Hoegh-Guldberg, O., and Fine, M. (2004). Low temperatures cause coral bleaching. Coral Reefs 23, 444-444. doi: 10.1007/s00338-004-0401-2

Hoogenboom, M. O., Frank, G. E., Chase, T. J., Jurriaans, S., Álvarez-Noriega, M., Peterson, K., et al. (2017). Environmental drivers of variation in bleaching severity of Acropora species during an extreme thermal anomaly. Front. Mar. Sci. 4:376. doi: 10.3389/fmars.2017.00376

Hughes, T. P., Anderson, K. D., Connolly, S. R., Heron, S. F., Kerry, J. T., Lough, J. M., et al. (2018a). Spatial and temporal patterns of mass bleaching of corals in the Anthropocene. Science 359, 80-83. doi: 10.1126/science.aan8048

Hughes, T. P., Kerry, J. T., Baird, A. H., Connolly, S. R., Dietzel, A., Eakin, C. M., et al. (2018b). Global warming transforms coral reef assemblages. Nature 556, 492-496. doi: 10.1038/s41586-018-0041-2

Hughes, T. P., Kerry, J. T., Álvarez-Noriega, M., Álvarez-Romero, J. G., Anderson, K. D., Baird, A. H., et al. (2017). Global warming and recurrent mass bleaching of corals. Nature 543, 373-377. doi: 10.1038/nature21707

Idjadi, J. A., Lee, S. C., Bruno, J. F., Precht, W. F., Allen-Requa, L., and Edmunds, P. J. (2006). Rapid phase-shift reversal on a Jamaican coral reef. Coral Reefs 25 , 209-211. doi: 10.1007/s00338-006-0088-7

Jones, R. J., Hoegh-Guldberg, O., Larkum, A. W. D., and Schreiber, U. (1998). Temperature-induced bleaching of corals begins with impairment of the $\mathrm{CO} 2$ fixation mechanism in zooxanthellae. Plant Cell Environ. 21, 1219-1230. doi: 10.1046/j.1365-3040.1998.00345.x

Krueger, T., Becker, S., Pontasch, S., Dove, S., Hoegh-Guldberg, O., Leggat, W., et al. (2014). Antioxidant plasticity and thermal sensitivity in four types of Symbiodinium sp. J. Phycol. 50, 1035-1047. doi: 10.1111/jpy.12232

Krueger, T., Hawkins, T. D., Becker, S., Pontasch, S., Dove, S., Hoegh-Guldberg, O., et al. (2015). Differential coral bleaching-Contrasting the activity and response of enzymatic antioxidants in symbiotic partners under thermal stress. Comp. Biochem. Physiol. A Mol. Integr. Physiol. 190, 15-25. doi: 10.1016/j.cbpa.2015. 08.012

Krueger, T., Horwitz, N., Bodin, J., Giovani, M.-E., Escrig, S., Meibom, A., et al. (2017). Common reef-building coral in the Northern Red Sea resistant to elevated temperature and acidification. R. Soc. Open Sci. 4:170038. doi: 10.1098/ rsos. 170038

Krug, L. A., Gherardi, D. F. M., Stech, J. L., Leão, Z. M. A. N., Kikuchi, R. K. P., Hruschka, E. R., et al. (2013). The construction of causal networks to estimate coral bleaching intensity. Environ. Model. Soft. 42, 157-167. doi: 10.1016/j. envsoft.2013.01.003

Kvitt, H., Rosenfeld, H., and Tchernov, D. (2016). The regulation of thermal stress induced apoptosis in corals reveals high similarities in gene expression and function to higher animals. Sci. Rep. 6:30359. doi: 10.1038/srep 30359

LaJeunesse, T. C., Parkinson, J. E., Gabrielson, P. W., Jeong, H. J., Reimer, J. D., Voolstra, C. R., et al. (2018). Systematic revision of Symbiodiniaceae highlights the antiquity and diversity of coral endosymbionts. Curr. Biol 28, 2570-2580.e6. doi: 10.1016/j.cub.2018.07.008

Le Nohaï, M., Ross, C. L., Cornwall, C. E., Comeau, S., Lowe, R., Mcculloch, M. T., et al. (2017). Marine heatwave causes unprecedented regional mass bleaching of thermally resistant corals in northwestern Australia. Sci. Rep. 7:14999. doi: 10.1038/s41598-017-14794-y

Leggat, W., Camp, E. F., Suggett, D. J., Heron, S. F., Fordyce, A. J., Gardener, S., et al. (2019). Rapid coral decay is associated with marine heatwave mortality events on reefs. Curr. Biol. doi: 10.1016/j.cub.2019.06.077

Leggat, W., Seneca, F., Wasmund, K., Ukani, L., Yellowlees, D., and Ainsworth, T. D. (2011). Differential responses of the coral host and their algal symbiont to thermal stress. PLoS One 6:e26687. doi: 10.1371/journal.pone.0026687

Lentz, S. J., Churchill, J. H., Davis, K. A., Farrar, J. T., Pineda, J., and Starczak, V. (2016). The characteristics and dynamics of wave-driven flow across a platform coral reef in the Red Sea. J. Geophys. Res. Oceans 121, 1360-1376. doi: $10.1002 / 2015 j \mathrm{j} 011141$ 
Lesser, M. P. (1997). Oxidative stress causes coral bleaching during exposure to elevated temperatures. Coral Reefs 16, 187-192. doi: 10.1007/s00338005 0073

Lesser, M. P., and Farrell, J. H. (2004). Exposure to solar radiation increases damage to both host tissues and algal symbionts of corals during thermal stress. Coral Reefs 23, 367-377. doi: 10.1007/s00338-004-0392-z

Lirman, D., Schopmeyer, S., Manzello, D., Gramer, L. J., Precht, W. F., MullerKarger, F., et al. (2011). Severe 2010 cold-water event caused unprecedented mortality to corals of the Florida reef tract and reversed previous survivorship patterns. PLoS One 6:e23047. doi: 10.1371/journal.pone.0023047

Liu, G., Eakin, C. M., Rauenzahn, J. L., Christensen, T. R. L., Heron, S., Li, J., et al. (2012). "NOAA Coral Reef Watch's decision support system for coral reef management," in Proceedings of the 12th International Coral Reef Symposium, Cairns, QLD.

Liu, G., Heron, F. S., Eakin, M. C., Muller-Karger, E. F., Vega-Rodriguez, M., Guild, S. L., et al. (2014). Reef-Scale thermal stress monitoring of coral ecosystems: new $5-\mathrm{km}$ global products from NOAA coral reef watch. Remote Sens. 6, 11579-11606. doi: 10.3390/rs61111579

Liu, G., Skirving, W. J., Geiger, E. F., De La Cour, J. L., Marsh, B. L., Heron, S. F., et al. (2017). NOAA Coral Reef Watch's $5 \mathrm{~km}$ satellite coral bleaching heat stress monitoring product suite version 3 and four-month outlook version 4 . Reef Encount. 32, 39-45.

Liu, G., Strong, A., Skirving, W., and Arzayus, F. (2005). “Overview of NOAA coral reef watch program's near-real time satellite global coral bleaching monitoring activities," in Proceedings of the 10th International Coral Reef Symposium, Okinawa, 1783-1793.

Lowe, R. J., and Falter, J. (2014). Oceanic forcing of coral reefs. Annu. Rev. Mar. Sci. 7, 43-66. doi: 10.1146/annurev-marine-010814-015834

Loya, Y., Sakai, K., Yamazato, K., Nakano, Y., Sambali, H., and Van Woesik, R. (2001). Coral bleaching: the winners and the losers. Ecol. Lett. 4, 122-131. doi: 10.1046/j.1461-0248.2001.00203.x

MacKellar, M. C., and McGowan, H. A. (2010). Air-sea energy exchanges measured by eddy covariance during a localised coral bleaching event, Heron Reef, Great Barrier Reef, Australia. Geophys. Res. Lett. 37:L24703.

MacKellar, M. C., Mcgowan, H. A., and Phinn, S. R. (2013). An observational heat budget analysis of a coral reef, Heron Reef, Great Barrier Reef, Australia. J. Geophys. Res. Atmos. 118, 2547-2559. doi: 10.1002/jgrd.50270

Manzello, D., Hendee, J. C., Ward, D., and Hillis-Starr, Z. (2004). “An evaluation of environmental parameters coincident with the partial bleaching event in St. Croix, U. S. Virgin Islands 2003," in Proceedings of the 10th International Coral Reef Symposium, Okinawa, 709-717.

Manzello, D. P., Brandt, M., Smith, T. B., Lirman, D., Hendee, J. C., and Nemeth, R. S. (2007). Hurricanes benefit bleached corals. Proc. Natl. Acad. Sci. U.S.A. 104, 12035-12039. doi: 10.1073/pnas.0701194104

McClanahan, T. R., Baird, A. H., Marshall, P. A., and Toscano, M. A. (2004). Comparing bleaching and mortality responses of hard corals between southern Kenya and the Great Barrier Reef, Australia. Mar. Pollut. Bull. 48, 327-335. doi: 10.1016/j.marpolbul.2003.08.024

Middlebrook, R., Anthony, K. R. N., Hoegh-Guldberg, O., and Dove, S. (2010). Heating rate and symbiont productivity are key factors determining thermal stress in the reef-building coral Acropora formosa. J. Exp. Biol. 213, 1026-1034. doi: 10.1242/jeb.031633

Moore, J. A. Y., Bellchambers, L. M., Depczynski, M. R., Evans, R. D., Evans, S. N., Field, S. N., et al. (2012). Unprecedented mass bleaching and loss of coral across $12^{\circ}$ of latitude in Western Australia in 2010-11. PLoS One 7:e51807. doi: 10.1371/journal.pone.0051807

Morgan, K. M., Perry, C. T., Johnson, J. A., and Smithers, S. G. (2017). Nearshore turbid-zone corals exhibit high bleaching tolerance on the Great Barrier Reef following the 2016 ocean warming event. Front. Mar. Sci. 4:224. doi: 10.3389/ fmars.2017.00224

Moum, J. N., and Smyth, W. (2001). Upper Ocean Mixing Processes. Oregon, OR: Academic Press.

Moya, A., Sakamaki, K., Mason, B. M., Huisman, L., Forêt, S., Weiss, Y., et al. (2016). Functional conservation of the apoptotic machinery from coral to man: the diverse and complex Bcl-2 and caspase repertoires of Acropora millepora. BMC Genomics 17:62. doi: 10.1186/s12864-015-2355-x

Murphy, M. P. (2009). How mitochondria produce reactive oxygen species. Biochem. J. 417, 1-13. doi: 10.1042/bj20081386
Muscatine, L., and Porter, J. W. (1977). Reef corals: mutualistic symbioses adapted to nutrient-poor environments. Bioscience 27, 454-460. doi: 10.2307/1297526

Mwachireya, S. A., Carreiro-Silva, M., Hartwick, B. E., and Mcclanahan, T. R. (2018). Terrestrial discharge influences microbioerosion and microbioeroder community structure in coral reefs. Afr. J. Mar. Sci. 40, 25-42. doi: 10.2989/ $1814232 x .2018 .1435424$

Nakamura, T. (2010). Importance of water-flow on the physiological responses of reef-building corals. Galaxea J. Coral Reef Stud. 12, 1-14. doi: 10.3755/galaxe a.12.1

Nitschke, M. R., Gardner, S. G., Goyen, S., Fujise, L., Camp, E. F., Ralph, P. J., et al. (2018). Utility of photochemical traits as diagnostics of thermal tolerance amongst great barrier reef corals. Front. Mar. Sci. 5:45. doi: 10.3389/fmars.2018. 00045

Oliver, E. C. J., Donat, M. G., Burrows, M. T., Moore, P. J., Smale, D. A., Alexander, L. V., et al. (2018). Longer and more frequent marine heatwaves over the past century. Nat. Commun. 9:1324. doi: 10.1038/s41467-018-03732-9

Perry, C. T., and Morgan, K. M. (2017). Bleaching drives collapse in reef carbonate budgets and reef growth potential on southern Maldives reefs. Sci. Rep. 7:40581. doi: 10.1038/srep40581

Perry, C. T., Murphy, G. N., Kench, P. S., Edinger, E. N., Smithers, S. G., Steneck, R. S., et al. (2014). Changing dynamics of Caribbean reef carbonate budgets: emergence of reef bioeroders as critical controls on present and future reef growth potential. Proc. Royal Soc. B 281:20142018. doi: 10.1098/rspb.2014.2018

Phongsuwan, N., and Chansang, H. (2012). Repeated coral bleaching in the Andaman Sea, Thailand, during the last two decades. Phuket Mar. Biol. Center Res. Bull. 71, 19-41.

Pratchett, M. S., Munday, P. L., Wilson, S., Graham, N., Cinner, J., Bellwood, D., et al. (2008). Effects of Climate-Induced Coral Bleaching on Coral-Reef Fishes: Ecological And Economic Consequences. Boca Raton, FL: CRC Press.

Quistad, S. D., Stotland, A., Barott, K. L., Smurthwaite, C. A., Hilton, B. J., Grasis, J. A., et al. (2014). Evolution of TNF-induced apoptosis reveals $550 \mathrm{My}$ of functional conservation. Proc. Natl. Acad. Sci. U.S.A. 111, 9567-9572. doi: 10. 1073/pnas.1405912111

Raymundo, L. J., Burdick, D., Lapacek, V. A., Miller, R., and Brown, V. (2017). Anomalous temperatures and extreme tides: Guam staghorn Acropora succumb to a double threat. Mar. Ecol. Prog. Ser. 564, 47-55. doi: 10.3354/meps12005

Reyes-Nivia, C., Diaz-Pulido, G., Kline, D., Guldberg, O. H., and Dove, S. (2013). Ocean acidification and warming scenarios increase microbioerosion of coral skeletons. Glob. Chang Biol. 19, 1919-1929. doi: 10.1111/gcb.12158

Riegl, B. M., Purkis, S. J., Al-Cibahy, A. S., Abdel-Moati, M. A., and HoeghGuldberg, O. (2011). Present limits to heat-adaptability in corals and population-level responses to climate extremes. PLoS One 6:e24802. doi: 10. 1371/journal.pone.0024802

Roberty, S., Fransolet, D., Cardol, P., Plumier, J. C., and Franck, F. (2015). Imbalance between oxygen photoreduction and antioxidant capacities in Symbiodinium cells exposed to combined heat and high light stress. Coral Reefs 34, 1063-1073. doi: 10.1007/s00338-015-1328-5

Robinson, J. P. W., Wilson, S. K., and Graham, N. A. J. (2019a). Abiotic and biotic controls on coral recovery 16 years after mass bleaching. Coral Reefs. 1-11. doi: 10.1007/s00338-019-01831-7

Robinson, J. P. W., Wilson, S. K., Jennings, S., and Graham, N. A. J. (2019b). Thermal stress induces persistently altered coral reef fish assemblages. Glob. Change Biol. 25, 2739-2750. doi: 10.1111/gcb.14704

Rogers, A., Blanchard, J. L., and Mumby, P. J. (2014). Vulnerability of coral reef fisheries to a loss of structural complexity. Curr. Biol. 24, 1000-1005. doi: 10.1016/j.cub.2014.03.026

Rosic, N. N., and Dove, S. (2011). Mycosporine-like amino acids from coral dinoflagellates. Appl. Environ. Microbiol. 77, 8478-8486. doi: 10.1128/AEM. 05870-11

Rosic, N. N., Pernice, M., Dove, S., Dunn, S., and Hoegh-Guldberg, O. (2011). Gene expression profiles of cytosolic heat shock proteins Hsp70 and Hsp90 from symbiotic dinoflagellates in response to thermal stress: possible implications for coral bleaching. Cell Stress Chaper. 16, 69-80. doi: 10.1007/s12192-0100222-X

Rosic, N. N., Pernice, M., Dunn, S., Dove, S., and Hoegh-Guldberg, O. (2010). Differential regulation by heat stress of novel cytochrome P450 genes from the dinoflagellate symbionts of reef-building corals. Appl. Environ. Microbiol. 76, 2823-2829. doi: 10.1128/AEM.02984-09 
Ruiz-Jones, L. J., and Palumbi, S. R. (2017). Tidal heat pulses on a reef trigger a fine-tuned transcriptional response in corals to maintain homeostasis. Sci. Adv. 3:e1601298. doi: 10.1126/sciadv.1601298

Sato, Y., Bourne David, G., and Willis Bette, L. (2009). Dynamics of seasonal outbreaks of black band disease in an assemblage of Montipora species at Pelorus Island (Great Barrier Reef, Australia). Proc. R. Soc. B Biol. Sci. 276, 2795-2803. doi: $10.1098 / \mathrm{rspb} .2009 .0481$

Schlegel, R. W. (2018). Marine Heatwave Tracker: The App to See When and Where Marine Heatwaves are Happening Around the World. Available at: http: //www.marineheatwaves.org/tracker (accessed July 1, 2019).

Schoepf, V., Stat, M., Falter, J. L., and Mcculloch, M. T. (2015). Limits to the thermal tolerance of corals adapted to a highly fluctuating, naturally extreme temperature environment. Sci. Rep. 5:17639. doi: 10.1038/srep17639

Seveso, D., Montano, S., Strona, G., Orlandi, I., Galli, P., and Vai, M. (2014). The susceptibility of corals to thermal stress by analyzing Hsp60 expression. Mar. Environ. Res. 99, 69-75. doi: 10.1016/j.marenvres.2014.06.008

Seveso, D., Montano, S., Strona, G., Orlandi, I., Galli, P., and Vai, M. (2016). Hsp60 expression profiles in the reef-building coral Seriatopora caliendrum subjected to heat and cold shock regimes. Mar. Environ. Res. 119, 1-11. doi: 10.1016/j.marenvres.2016.05.007

Shuail, D., Wiedenmann, J., D’angelo, C., Baird, A. H., Pratchett, M. S., Riegl, B., et al. (2016). Local bleaching thresholds established by remote sensing techniques vary among reefs with deviating bleaching patterns during the 2012 event in the Arabian/Persian Gulf. Mar. Pollut. Bull. 105, 654-659. doi: 10.1016/ j.marpolbul.2016.03.001

Silbiger, N., Guadayol, Ò., Thomas, F., and Donahue, M. (2015). Impacts of multiple environmental stressors on coral reef erosion and secondary accretion. PeerJ Preprints 3:e1451.

Skirving, W., Enríquez, S., Hedley, J., Dove, S., Eakin, C., Mason, R., et al. (2017). Remote sensing of coral bleaching using temperature and light: progress towards an operational algorithm. Remote Sens. 10:18. doi: 10.3390/rs10010018

Skirving, W., Heron, M., and Heron, S. (2006). The hydrodynamics of a bleaching event: implications for management and monitoring. Coral Reefs and Climate Changed Science and Management. Coast. Estuar. Stud. 61, 145-161.

Smale, D. A., and Wernberg, T. (2012). Ecological observations associated with an anomalous warming event at the Houtman Abrolhos Islands, Western Australia. Coral Reefs 31, 441-441. doi: 10.1007/s00338-012-0873-4

Smale, D. A., Wernberg, T., Oliver, E. C. J., Thomsen, M., Harvey, B. P., Straub, S. C., et al. (2019). Marine heatwaves threaten global biodiversity and the provision of ecosystem services. Nat. Clim. Change 9, 306-312. doi: 10.1038/ s41558-019-0412-1

Smale, D. A., Wernberg, T., and Vanderklift, M. A. (2017). Regional-scale variability in the response of benthic macroinvertebrate assemblages to a marine heatwave. Mar. Ecol. Prog. Ser. 568, 17-30. doi: 10.3354/meps12080

Smith, N. P. (2001). Weather and hydrographic conditions associated with coral bleaching: lee stocking Island, Bahamas. Coral Reefs 20, 415-422. doi: 10.1007/ s00338-001-0189-2

Strychar, K. B., Coates, M., Sammarco, P. W., and Piva, T. J. (2004). Bleaching as a pathogenic response in scleractinian corals, evidenced by high concentrations of apoptotic and necrotic zooxanthellae. J. Exp. Mar. Biol. Ecol. 304, 99-121. doi: 10.1016/j.jembe.2003.11.023

Strychar, K. B., and Sammarco, P. W. (2009). Exaptation in corals to high seawater temperatures: low concentrations of apoptotic and necrotic cells in host coral tissue under bleaching conditions. J. Exp. Mar. Biol. Ecol. 369, 31-42. doi: 10.1016/j.jembe.2008.10.021

Stuart-Smith, R. D., Brown, C. J., Ceccarelli, D. M., and Edgar, G. J. (2018). Ecosystem restructuring along the Great Barrier Reef following mass coral bleaching. Nature 560, 92-96. doi: 10.1038/s41586-018-0359-9

Swain, T. D., Vega-Perkins, J. B., Oestreich, W. K., Triebold, C., Dubois, E., Henss, J., et al. (2016). Coral bleaching response index: a new tool to standardize and compare susceptibility to thermal bleaching. Glob. Change Biol. 22, 2475-2488. doi: $10.1111 /$ gcb.13276

Takahashi, S., Whitney, S., Itoh, S., Maruyama, T., and Badger, M. (2008). Heat stress causes inhibition of the de novo synthesis of antenna proteins and photobleaching in cultured Symbiodinium. Proc. Natl. Acad. Sci. U.S.A. 105, 4203-4208. doi: 10.1073/pnas.0708554105

Takahashi, S., Whitney, S. M., and Badger, M. R. (2009). Different thermal sensitivity of the repair of photodamaged photosynthetic machinery in cultured
Symbiodinium species. Proc. Natl. Acad. Sci. U.S.A. 106, 3237-3242. doi: 10. 1073/pnas.0808363106

Takahashi, S., Yoshioka-Nishimura, M., Nanba, D., and Badger, M. R. (2013). Thermal acclimation of the symbiotic alga Symbiodinium spp. alleviates photobleaching under heat stress. Plant Physiol. 161, 477-485. doi: 10.1104/pp. 112.207480

Talley, L. D., Pickard, G. L., Emery, W. J., and Swift, J. H. (2011). "Mass, salt, and heat budgets and wind forcing," in Descriptive Physical Oceanography, ed. L. D. Talley (Cambridge, MA: Academic Press), 111-145. doi: 10.1016/b978-0-75064552-2.10005-8

Tchernov, D., Gorbunov, M. Y., De Vargas, C., Narayan Yadav, S., Milligan, A. J., Häggblom, M., et al. (2004). Membrane lipids of symbiotic algae are diagnostic of sensitivity to thermal bleaching in corals. Proc. Natl. Acad. Sci. U.S.A. 101, 13531-13535. doi: 10.1073/pnas.0402907101

Tchernov, D., Kvitt, H., Haramaty, L., Bibby, T. S., Gorbunov, M. Y., Rosenfeld, H., et al. (2011). Apoptosis and the selective survival of host animals following thermal bleaching in zooxanthellate corals. Proc. Natl. Acad. Sci. U.S.A. 108, 9905-9909. doi: 10.1073/pnas.1106924108

Traylor-Knowles, N., Rose, N. H., Sheets, E. A., and Palumbi, S. R. (2017). Early transcriptional responses during heat stress in the coral Acropora hyacinthus. Biol. Bull. 232, 91-100. doi: 10.1086/692717

Tribollet, A. (2008a). Dissolution of dead corals by euendolithic microorganisms across the northern Great Barrier Reef (Australia). Microb. Ecol. 55, 569-580.

Tribollet, A. (2008b). "The boring microflora in modern coral reef ecosystems: A review of its roles," in Current Developments in Bioerosion. Erlangen Earth Conference Series, eds M. Wisshak and L. Tapanila (Berlin: Springer).

Tribollet, A., Decherf, G., Hutchings, P., and Peyrot-Clausade, M. (2002). Largescale spatial variability in bioerosion of experimental coral substrates on the Great Barrier Reef (Australia): importance of microborers. Coral Reefs 21, 424-432. doi: 10.1007/s00338-002-0267-0

Tribollet, A., Godinot, C., Atkinson, M., and Langdon, C. (2009). Effects of elevated $\mathrm{pCO} 2$ on dissolution of coral carbonates by microbial euendoliths. Glob. Biogeochem. Cycles 23:GB3008. doi: 10.1029/2008GB00 3286

Tribollet, A., and Golubic, S. (2005). Cross-shelf differences in the pattern and pace of bioerosion of experimental carbonate substrates exposed for 3 years on the northern Great Barrier Reef, Australia. Coral Reefs 24, 422-434. doi: 10.1007/s00338-005-0003-7

Tribollet, A., and Golubic, S. (2011). "Reef bioerosion: Agents and processes," in Coral Reefs: An Ecosystem in Transition, eds Z. Dubinsky and N. Stambler (Dordrecht: Springer), 435-449. doi: 10.1371/journal.pone.0045124

Tudhope, A. W., and Risk, M. (1985). Rate of dissolution of carbonate sediments by microboring organisms, Davies Reef, Australia. J. Sediment. Res. 55, 440-447. doi: 10.1306/212F86F7-2B24-11D7-8648000102C1865D

Van Hooidonk, R., Maynard, J. A., and Planes, S. (2013). Temporary refugia for coral reefs in a warming world. Nat. Clim. Change 3, 508-511. doi: 10.1038/ nclimate 1829

Van Woesik, R., Irikawa, A., and Loya, Y. (2004). "Coral Bleaching: Signs of Change in Southern Japan," in Coral Health and Disease, eds E. Rosenberg and Y. Loya (Berlin: Springer Berlin Heidelberg), 119-141.

Van Wynsberge, S., Menkes, C., Le Gendre, R., Passfield, T., and Andréfouët, S. (2017). Are sea surface temperature satellite measurements reliable proxies of lagoon temperature in the South Pacific? Estuar. Coast. Shelf Sci. 199, 117-124. doi: 10.1016/j.ecss.2017.09.033

Vergés, A., Vanderklift, M. A., Doropoulos, C., and Hyndes, G. A. (2011). Spatial patterns in herbivory on a coral reef are influenced by structural complexity but not by algal traits. PLoS One 6:e17115. doi: 10.1371/journal.pone.0017115 doi: 10.1371/journal.pone.0017115

Vogel, K., Gektidis, M., Golubic, S., Kiene, W. E., and Radtke, G. (2000). Experimental studies on microbial bioerosion at Lee Stocking Island, Bahamas and One Tree Island, Great Barrier Reef, Australia: implications for paleoecological reconstructions. Lethaia 33, 190-204. doi: 10.1080/ 00241160025100053

Walter, P., and Ron, D. (2011). The Unfolded protein response: from stress pathway to homeostatic regulation. Science 334, 1081-1086. doi: 10.1126/ science.1209038 doi: 10.1126/science.1209038

Weeks, S. J., Anthony, K. R. N., Bakun, A., Feldman, G. C., and Guldberg, O. H. (2008). Improved predictions of coral bleaching using seasonal baselines and 
higher spatial resolution. Limnol. Oceanogr. 53, 1369-1375. doi: 10.4319/lo. 2008.53.4.1369

Weller, E., Nunez, M., Meyers, G., and Masiri, I. (2008). A climatology of oceanatmosphere heat flux estimates over the Great Barrier Reef and Coral Sea: implications for recent mass coral bleaching events. J. Clim. 21, 3853-3871. doi: 10.1175/2007JCLI2085.1

Wernberg, T., Smale, D. A., Tuya, F., Thomsen, M. S., Langlois, T. J., De Bettignies, T., et al. (2012). An extreme climatic event alters marine ecosystem structure in a global biodiversity hotspot. Nat. Clim. Change 3, 78-82. doi: 10.1038/ nclimate 1627

Wu, R., Kirtman, B. P., and Pegion, K. (2007). Surface latent heat flux and its relationship with sea surface temperature in the National Centers for Environmental Prediction Climate Forecast System simulations and retrospective forecasts. Geophys. Res. Lett. 34:L17712. doi: 10.1029/2007GL030751

Yellowlees, D., Rees, T. A. V., and Leggat, W. (2008). Metabolic interactions between algal symbionts and invertebrate hosts. Plant Cell Environ. 31, 679-694. doi: 10.1111/j.1365-3040.2008.01802.x

Zelinka, M. D., and Hartmann, D. L. (2010). Why is longwave cloud feedback positive? J. Geophys. Res. 115:D16117. doi: 10.1029/2010JD013817

Zepp, R. G., Shank, G. C., Stabenau, E., Patterson, K. W., Cyterski, M., Fisher, W., et al. (2008). Spatial and temporal variability of solar ultraviolet exposure of coral assemblages in the Florida keys: importance of colored dissolved organic matter. Limnol. Oceanogr. 53, 1909-1922. doi: 10.2307/4005 8307

Zhang, Z., Lowe, R., Ivey, G., Xu, J., and Falter, J. (2016). The combined effect of transient wind-driven upwelling and eddies on vertical nutrient fluxes and phytoplankton dynamics along Ningaloo Reef, Western Australia. J. Geophys. Res. Oceans 121, 4994-5016. doi: 10.1002/2016JC01 1791

Conflict of Interest Statement: The authors declare that the research was conducted in the absence of any commercial or financial relationships that could be construed as a potential conflict of interest.

The reviewer SW declared a past co-authorship with one of the authors SH to the handling Editor.

Copyright $\odot 2019$ Fordyce, Ainsworth, Heron and Leggat. This is an open-access article distributed under the terms of the Creative Commons Attribution License (CC BY). The use, distribution or reproduction in other forums is permitted, provided the original author(s) and the copyright owner(s) are credited and that the original publication in this journal is cited, in accordance with accepted academic practice. No use, distribution or reproduction is permitted which does not comply with these terms. 